\title{
Characterization of a thermotolerant ROK-type mannofructokinase from Streptococcus mitis: application to the synthesis of phosphorylated sugars
}

Carine Vergne-Vaxelaire,

Aline Mariage, 1

Jean-Louis Petit, 1

Aurélie Fossey-Jouenne, 1

Christine Guérard-Hélaine, 2,3

Ekaterina Darii, 1

Adrien Debard, 1

Stessy Nepert, 1

Virginie Pellouin, 1

Marielle Lemaire, 2,3

Anne Zaparucha, 1

Marcel Salanoubat, 1

Véronique de Berardinis, $1 \square$

Emailvberard@genoscope.cns.fr

Génomique métabolique, Genoscope, Institut François Jacob, CEA, CNRS, Univ Evry, Université Paris-Saclay, 91057 Evry, France AQ1

2 Clermont Université, Université Blaise Pascal, ICCF, BP 10448, 63000 Clermont-Ferrand, France

3 CNRS, UMR 6296, BP 8002663177, Aubière, France

Received: 2 February 2018 / Accepted: 10 April 2018 


\section{Abstract}

Most of the "repressor, open reading frame, kinase" (ROK) proteins already characterized so far, and exhibiting a kinase activity, take restrictedly Dglucose as substrate. By exploring the sequenced bacterial diversity, 61 ATPdependent kinases belonging to the ROK family have been identified and experimentally assayed for the phosphorylation of hexoses. These kinases were mainly found to be thermotolerant and highly active toward D-mannose and D-fructose with notable activities toward D-tagatose. Among them, the ATP-dependent kinase from the mesophile Streptococcus mitis (named $\mathrm{ScrK}_{\text {mitis }}$ ) was biochemically characterized and its substrate spectrum further studied. This enzyme possessed impressive catalytic efficiencies toward Dmannose and D-fructose of $1.510^{6} \mathrm{~s}^{-1} \mathrm{M}^{-1}$ and $2.710^{5} \mathrm{~s}^{-1} \mathrm{M}^{-1}$, respectively, but also significant ones toward D-tagatose $\left(3.510^{2} \mathrm{~s}^{-1} \mathrm{M}^{-1}\right)$ and the unnatural

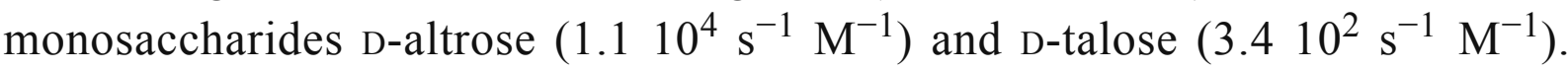
Specific activities measured for all hexoses showed a high stereopreference for D- over L-series. As proof of concept, 8 hexoses were phosphorylated in moderate to good yields, some of them described for the first time like Lsorbose-5-phosphate unusually phosphorylated in position 5. Its thermotolerance, its wide $\mathrm{pH}$ tolerance (from 7 to 10 ), and temperature range (>85\% activity between 40 and $70{ }^{\circ} \mathrm{C}$ ) open the way to applications in the enzymatic synthesis of monophosphorylated hexoses.

\section{Keywords}

Hexokinase

Fructokinase

Thermotolerance

ROK family

Phosphorylated sugars

Promiscuity

Carine Vergne-Vaxelaire and Aline Mariage contributed equally to this work.

Electronic supplementary material

The online version of this article ( https://doi.org/10.1007/s00253-018-9018-1) contains supplementary material, which is available to authorized users.

\section{Introduction}


Phosphorylation of monosaccharides is a highly important stage of carbohydrate metabolism in prokaryotes, mainly for preparing carbohydrates for degradation and transfer reactions but also as a mean of uptake. This reaction is catalyzed by sugar kinases such as glucokinases (EC 2.7.1.2), fructokinases (EC 2.7.1.4), and hexokinases (EC 2.7.1.1). While hexokinases, mostly reported among eukaryotes, exhibit broad substrate range tolerance, other sugar kinases have narrow sugar substrate specificity. Many bacterial sugar kinases are grouped into the ROK family (repressor, open reading frame, kinase), a large family of sugar metabolism-related proteins (Conejo et al. 2010; Larion et al. 2007; Titgemeyer et al. 1994).

Enzymatic syntheses of mono $O$-phosphorylated sugars have been described in the literature (Wohlgemuth et al. 2017) especially by transketolase- or aldolasecatalyzed C-C bond formation or by selective phosphorylation catalyzed by kinases (Charmantray et al. 2009; Guérard-Hélaine et al. 2014; Hélaine et al. 2015; Sánchez-Moreno et al. 2012; Shaeri et al. 2008; Wohlgemuth et al. 2017). Chiral phosphorylated sugars are of importance as central metabolites in the non-oxidative pentose phosphate pathway, in the Calvin cycle, and of particular interest for the study of various metabolic diseases such as diabetes, cancer, immunodeficiency, atherosclerosis, mucoviscidosis (Desvergnes et al. 2012), as well as unintended virus or microorganism developments (Shaeri et al. 2008, Wohlgemuth 2009, Solovjeva and Kochetov 2008, Schorken 1998). Given the vital roles of such compounds and, more particularly, of phosphorylated hexoses for metabolism studies but also organic chemistry, new kinases allowing their straightforward synthesis are needed. Among established strategies to provide enzymes possessing new or improved properties, exploring protein natural diversity is one of the most efficient (Bastard et al. 2014; Davids et al. 2013; de Berardinis et al. 2017; Guérard-Hélaine et al. 2015; Vergne-Vaxelaire et al. 2013; Zhao et al. 2013). In this study, we explored the sequenced bacterial diversity to find novel ATP-dependent C6 sugar kinases able to phosphorylate unusual various substrates such as D-tagatose, D-psicose and L-sorbose, rare or unnatural hexoses. Among the 61 ATP-dependent kinases found to be active toward various hexoses, a thermotolerant kinase from Streptococcus mitis $\left(\mathrm{ScrK}_{\text {mitis }}\right)$ was selected to be further studied and its biocatalytic capabilities were characterized. Data regarding substrate promiscuity, reaction conditions ( $\mathrm{pH}$ and temperature), biochemical properties, as well as the structural identification of some phosphorylated compounds, were provided.

\section{Materials and methods}

\section{Chemicals and materials}


All chemical reagents were purchased from commercial sources and used without additional purification. D- $(+)-$ and L-(-)-allose, D- $(+)$ and L-(-)-altrose, L-(-)-mannose, D-(-)- and L-(+)-gulose, D $-(+)-$ and L-(-)-idose, L-(-)-galactose, D- $(+)$ - and L-(-)-talose, L-psicose, L- $(+)$-fructose, and L- $(+)$-tagatose were purchased from Carbosynth (Compton, berkshire, UK). D-(-)-fructose, Dpsicose, D- $(+)$ - and L-(-)-sorbose, D-(-)-tagatose, D- $(+)-$ and L-(-)-glucose, D$(+)$-mannose, D- $(-)$ - and L-(+)-threose, D-xylulose, D- $(-)$-lyxose, D- $(+)$-xylose, D$(-)$ - and L- $(+)$-arabinose, D- $(-)$-ribose, $\mathrm{D}-(-)$ - and L- $(+)$-erythrose, $\mathrm{D}-(+)-$ galactose, L-(+)-erythrulose, D- $(+)$-cellobiose and $\mathrm{N}$-acetyl- D- $(+)$-glucosamine, adenosine triphosphate (ATP), phosphoenolpyruvic acid monopotassium salt (PEP), $\beta$-Nicotinamide adenine dinucleotide reduced (NADH) and $\beta$ Nicotinamide adenine dinucleotide (NAD), isopropyl- $\beta$ - D-thiogalactoside (IPTG), 2-( $N$-morpholino)ethanesulfonic acid (MES), 2-Amino-2-

(hydroxymethyl)-1,3-propanediol, enzymes lactate dehydrogenase (LD), and pyruvate kinase (PK) from rabbit muscle were purchased from Sigma Aldrich (MilliporeSigma, StLouis, USA). Bovine serum albumin was purchased from Bio-Rad. Oligonucleotides were from Sigma-Aldrich (MilliporeSigma, StLouis, USA). E. coli strains BL21-CodonPlus (DE3)-RIPL were from Agilent technologies (Santa Clara, USA). Enzymatic spectrophotometric screenings in microplates were performed on a SpectraMax Plus384 (Molecular Devices, Sunnyvale, USA). Spectrophometric assays of $\mathrm{ScrK}_{\text {mitis }}$ were recorded on a Safas UVMC2 (Safas, Monaco) thermostated when specified with a refrigerated/heating circulator Corio CD-200F (Jubalo ${ }^{\circledR}$, Seelbach, Germany) using microcells high-precision cell quartz with 10-mm light path (Hellma Analytics, Müllheim, Germany). Cell crude extracts in 96-microwell plates were heated using a tested thermocycler GeneAmpTM PCR system 9700 (Applied Biosystem, Foster City, USA). NMR spectra were recorded on a Bruker (Bruker, Billerica, USA) 300 or $600 \mathrm{MHz}$ spectrometer (Evry University, France) for ${ }^{1} \mathrm{H}$ and ${ }^{13} \mathrm{C}$ experiments, and on a Bruker $500 \mathrm{MHz}$ (ICSN, France) for ${ }^{1} \mathrm{H}_{-}{ }^{31} \mathrm{P}$ experiments. Chemical shifts are expressed in ppm and referenced with residual solvent signals. Coupling constant values $(J)$ are given in hertz. NMR spectra of $\alpha$ form and $\beta$ form are respectively noted as $\alpha$ and $\beta$. UHPLC analyses were performed on a UHPLC U3000 RS 1034 bar (Thermo Fisher Scientific, Waltham, USA) equipped with diode array detector DAD3000 and an evaporative light scattering detector (ELSD) 6100 (Esa Chromachem ${ }^{\circledR}$ ). HPLC purifications were done on a semi-preparative HPLC system prominence LC20AP (Shimadzu, Kyoto, Japan) equipped with an ELSD-LTII (Shimadzu, Kyoto, Japan) and a fraction collector FRC-10A (Shimadzu, Kyoto, Japan). LCHRMS analyses were performed on a Thermo Scientific ${ }^{\mathrm{TM}}$ Dionex $^{\mathrm{TM}}$ UltiMate $^{\mathrm{TM}}$ 3000 thermostated column compartment rapid separation (TCC-3000RS) LC system (Thermo Fisher Scientific, Waltham, USA) coupled to ultra-high 
resolution Orbitrap Elite hybrid mass spectrometer (Thermo Fisher Scientific, Waltham, USA) equipped with electrospray ionization (ESI) source. Ion exchange column purifications were performed on a Dowex ${ }^{\circledR} 1$ 1X8-200-400 mesh resin purchased from Acros Organics (Thermo Fisher Scientific, Waltham, USA).

\section{Cloning, expression, and purification}

Primers were chosen and genes were cloned with a histidine tag in N-terminal part in a pET22b(+) (Novagen) modified for ligation independent cloning as already described (Bastard et al. 2014). All primers and strains of the 90 selected ROK-type kinases are listed in Table S1 and named from KIN1 to KIN90. All the strains along with their identifiers were purchased from DSMZ, CIP, or ATCC collections. When DNA samples corresponding to the gene encoding the selected enzyme was not available, PCR was performed on the DNA of another strain from the same species as noted in Table S1. All sequences were verified. In these cases, when the protein sequence or the strain is not identical to that of the selected enzyme, the sequence was deposited to the European Nucleotide Archive (ENA) with ENA id listed in Table S1. Assigned Uniprot id are A0A2K4X4D6, A0A2K4X4G8, A0A2K4X4D1, A0A2K4X4E5, A0A2K4X4D2, A0A2K4X4E4, A0A2K4X4I2, and A0A2K4X4C6. Each expression plasmid was transformed into Escherichia coli BL21-CodonPlus (DE3)-RIPL. Cell culture, induction of protein production, and cell lysis were conducted as previously published (Bastard et al. 2014). Enzymes were purified in 96 microwells using HisLink ${ }^{\mathrm{TM}} 96$ protein purification system (Promega). The elution buffer was $50 \mathrm{mM}$ glycylglycine (pH 7.5), $50 \mathrm{mM} \mathrm{NaCl}, 250 \mathrm{mM}$ imidazole, and 10\% glycerol. Samples were analyzed by SDS-PAGE using the NuPAGE system (Invitrogen), see Table S2. Large-scale purification of ScrK mitis $_{\text {was conducted }}$ from a $400-\mathrm{mL}$ culture as described elsewhere (Kreimeyer et al. 2007). The storage buffer was Tris $\mathrm{pH} 8,50 \mathrm{mM}, \mathrm{NaCl} 50 \mathrm{mM}, 1 \mathrm{mM}$ DTT, and glycerol $15 \%$. Purified enzymes were stored at $-80{ }^{\circ} \mathrm{C}$. The sample was analyzed by SDS-PAGE using the NuPAGE system. Protein concentration was determined by the Bradford method, with bovine serum albumin as the standard (Bio-Rad). Size exclusion chromatography was conducted on Superdex using a 200 10/300GL increase column (GE Healthcare Life Sciences).

\section{Enzymatic screening assay}

General screenings conducted in 384-microwell plates were done by spectrophotometry analysis (SpectraMax Plus384 (Molecular Devices, Sunnyvale, USA)) at $25{ }^{\circ} \mathrm{C}$ in a final volume of $70 \mu \mathrm{L}$. ATP-dependent activities for phosphorylation were determined by monitoring the consumption of the 
NADH spectrophotometrically at $A_{340}$ using the coupled assay (Jaworek and Welsch 1985) employing pyruvate kinase (PK) and lactate dehydrogenase (LD) according to Beer-Lambert's law and molar absorptivity of $\beta$-NADH $(\varepsilon=$ $6220 \mathrm{M}^{-1} \mathrm{~cm}^{-1}$ ). The assay mixture comprised $30 \mathrm{mM}$ substrate, $0.2 \mathrm{mM}$ NADH, $2.5 \mathrm{mM}$ ATP, $5 \mathrm{mM} \mathrm{MgCl} 2,5 \mathrm{mM}$ PEP, $1 \mathrm{U}$ PK, $2.3 \mathrm{U} \mathrm{LD}$, and $50 \mathrm{mM}$ glycylglycine buffer $\mathrm{pH}$ 7.5. The reaction was initiated by addition of $10 \mu \mathrm{L}$ of purified enzyme (average of $500 \mu \mathrm{g} / \mathrm{mL}$ ). The background noise was estimated and removed for each enzyme with a supplemental microplate similarly treated but with a mixture lacking hexose substrate.

\section{ROK signatures analysis}

Pairwise sequence alignments were performed using Clustal Omega website ( https://www.ebi.ac.uk/Tools/msa/clustalo/ ). The 61 ROK-type kinases and the ROK-type sugar kinases from the literature (Table S3, S4 and S5) were used for the alignment analysis. ROK signatures were searched according to Conejo's work (Conejo et al. 2010).

\section{Phylogenetic analyses}

A careful inventory of "known" ROK-type sugar kinases was done searching as exhaustive as possible fructo-, glucose-, and hexo-kinases described in the literature and related to experimental data. Using Swissprot database information's, only proteins sharing the Interpro signature IPR000600 specific of ROK family were selected and listed in Table S4 and S5. These ROK kinases were aligned together with the 61 kinases of this study. Pairwise sequence alignments were calculated with gapped BLASTp and the BLOSUM62 scoring matrix. Phylogenetic analysis was performed using MAFFT (Katoh et al. 2002) for multiple sequence alignment, QUICKTREE (Howe et al. 2002) for tree building, and iTOL (Letunic and Bork 2016) for tree rendering. All the UniprotKB identifiers of the enzyme are reported in the phylogenetic trees. Specific activities (Table S3) of the 61 kinases were quantitatively symbolized and reported in the phylogenetic tree. ROK-type sugar kinases from the literature have been included and the activities described in their corresponding article (Table S4 and Table S5) were qualitatively reported in the phylogenetic tree. In addition, 3 known ROK-type repressors (XylR from Bacillus subtilis (Kreuzer et al. 1989) and Staphylococcus xylosus (Sizemore et al. 1991) and NagC from E. coli (Plumbridge 2001) were added. Respective Uniprot id were $\mathrm{P} 16557, \mathrm{P} 27159$, and P0AF20.

\section{Enzymes thermotolerance}


Volumes of $200 \mu \mathrm{L}$ of cell crude extracts in 96 microwells were incubated at $70{ }^{\circ} \mathrm{C}$ for $20 \mathrm{~min}$ in thermocycler. The microplates were centrifuged at $4000 \mathrm{rpm}$ for $20 \mathrm{~min}$ in a centrifuge 5810R (Eppendorf). Supernatants were transferred in a new microplate, analyzed by SDS-PAGE using the E-PAGE High-Throughput Gel system (Invitrogen), and specific activity measured. Protein concentrations were determined by the Bradford method, with bovine serum albumin as standard (Bio-Rad). ATP-dependent activities for phosphorylation of D-fructose, D-tagatose, and D-glucose were determined by monitoring the consumption of the NADH spectrophotometrically as described for the enzymatic screening assay.

\section{Characterization of $\mathrm{ScrK}_{\text {mitis }}$}

All specific activities and kinetic parameters were determined from duplicate experiments by monitoring the consumption of the NADH spectrophotometrically as described for the enzymatic screening assay. All reactions (except when notified) were performed on purified $\mathrm{ScrK}_{\text {mitis }}$ at $25{ }^{\circ} \mathrm{C}$ in $100-\mu \mathrm{L}$ scale using microcuvettes.

Protocol $A$ : The assay mixture $(100 \mu \mathrm{L})$ comprised $50 \mathrm{mM}$ hexose (except for D-fructose $2.5 \mathrm{mM}$ ), $0.2 \mathrm{mM}$ NADH, $2.5 \mathrm{mM}$ ATP, $5 \mathrm{mM}$ metal ion, $5 \mathrm{mM}$ phosphoenolpyruvate (PEP), $1 \mathrm{U} \mathrm{PK}, 2.3 \mathrm{U} \mathrm{LD}$, and $50 \mathrm{mM}$ glycylglycine buffer $\mathrm{pH}$ 7.5. The initial slope measured at $340 \mathrm{~nm}$ for 10 min after addition of purified $\mathrm{ScrK}_{\text {mitis }}$ determined the specific activity of the enzyme.

Protocol B: Protocol carried out in end-point to ensure the independence of the pyruvate kinase and lactate dehydrogenase assay system previously validated between $\mathrm{pH} 6.5$ and 9 (data not shown). Assay mixture was composed of $2.5 \mathrm{mM}$ D-fructose, $2.5 \mathrm{mM}$ neutralized ATP, $5 \mathrm{mM} \mathrm{MgCl}_{2}$, and $50 \mathrm{mM}$ specified buffer at specified $\mathrm{pH}$. To $100 \mu \mathrm{L}$ of the assay mixture preincubated $3 \mathrm{~min}$ at the specified temperature was added purified $\mathrm{ScrK}_{\text {mitis }}$ and the reaction was stirred at $400 \mathrm{rpm}$ for $2 \mathrm{~min}$ at the specified temperature. After acidic quench to $\mathrm{pH}=1(\mathrm{HCl} 4-10 \mathrm{M})$, neutralization to pH 6.5-9 (KOH 4-10 M), the ADP formed was assayed by pyruvate kinase and lactate dehydrogenase system (0.2 mM NADH, 1 U PK, $5 \mathrm{mM}$ neutralized PEP, 2.3 U LD) by measuring the difference in absorbance at $340 \mathrm{~nm}$ after total consummation of ADP.

(i) Specific activities of $\mathrm{ScrK}_{\text {mitis }}$ toward various substrates. Specific activities of $\mathrm{ScrK}_{\text {mitis }}$ were determined by using protocol A with $\mathrm{MgCl}_{2}$ as metal ion. Tested substrates were (D- and L-form) allose, altrose, glucose, mannose, 
gulose, idose, galactose, talose, psicose, fructose, sorbose, tagatose, arabinose, erythrose, and threose. In addition, D-ribose, D-xylose, D-lyxose, D-xylulose, L-erythrulose, D-cellobiose, and $N$-acetyl-D-glucosamine were also assayed.

(ii) Thermotolerance of $\mathrm{ScrK}_{\text {mitis }}$. Thermotolerance of $\mathrm{ScrK}_{\text {mitis }}$ was confirmed with a cell crude extract obtained as already described (Kreimeyer et al. 2007) from $100 \mathrm{~mL}$ of culture. A volume of $8 \mathrm{~mL}$ of cell crude extract was incubated $20 \mathrm{~min}$ at $70{ }^{\circ} \mathrm{C}$ and centrifuged at $8000 \mathrm{rpm}$ $30 \mathrm{~min}$. The clear cell crude extract was analyzed by SDS-PAGE using the $\mathrm{Nu}$-PAGE system (Invitrogen). Protein concentrations were determined by the Bradford method, with bovine serum albumin as standard (Bio-Rad). Specific activity of $\mathrm{ScrK}_{\text {mitis }}$ was measured with protocol A for D-fructose, D-mannose, and D-glucose.

(iii) Specific activity of $\mathrm{ScrK}_{\text {mitis }}$ versus $\mathrm{pH} /$ buffer solution. The protocol B was used at room temperature with the following buffers: MES buffer (pH 4.5-6.8), TRIS HCl buffer ( $\mathrm{pH}$ 6.8-9.6), glycylglycine $\mathrm{NaOH}$ buffer (pH 7.0-12.4), TRIS NaOH buffer (pH 11.0-12.4).

(iv) Specific activity of $\mathrm{ScrK}_{\text {mitis }}$ versus temperature. The protocol B was used in glycylglycine buffer $\mathrm{pH} 7.5$ at 15, 20, 30, 40, 45, 50, 55, 60, 65, 70 , and $80^{\circ} \mathrm{C}$.

(v) Specific activity of $\mathrm{ScrK}_{\text {mitis }}$ versus metal ions: the protocol A was used with $2.5 \mathrm{mM}$ of D-fructose. Tested inorganic salt at $5 \mathrm{mM}$ were $\mathrm{MgCl}_{2}$, $\mathrm{MnCl}_{2}, \mathrm{CoCl}_{2}, \mathrm{NiCl}_{2}, \mathrm{ZnCl}_{2}, \mathrm{CuCl}_{2}$, or $\mathrm{CaCl}_{2}$.

(vi) Determination of kinetic parameters of $\mathrm{ScrK}_{\text {mitis }}$. Kinetic constants were determined on purified $\mathrm{ScrK}_{\text {mitis }}$ by using the spectrophotometric coupled assay employing pyruvate kinase and lactate dehydrogenase system. Assay mixture was composed of $0.25 \mathrm{mM} \mathrm{NADH}, 2.5 \mathrm{mM}$ ATP, $5 \mathrm{mM}$ $\mathrm{MgCl}_{2}, 5 \mathrm{mM}$ PEP, $1 \mathrm{U}$ PK, $2.3 \mathrm{U} \mathrm{LD}$, and $50 \mathrm{mM}$ glycylglycine buffer $\mathrm{pH}$ 7.5. The kinetic constants for ATP were determined with $0.25 \mathrm{mM}$ $\mathrm{NADH}, 10 \mathrm{mM}$ D-fructose, $5 \mathrm{mM} \mathrm{MgCl} 2,5 \mathrm{mM}$ PEP, $1 \mathrm{U}$ PK, $2.3 \mathrm{U} \mathrm{LD}$, and $50 \mathrm{mM}$ glycylglycine buffer $\mathrm{pH}$ 7.5. The following substrate concentrations were used: ATP from 0.005 to $2.5 \mathrm{mM}$, D-fructose from 0.1 to $10 \mathrm{mM}$, D-altrose from 1 to $100 \mathrm{mM}$, D-mannose from 0.01 to $20 \mathrm{mM}$, D-glucose from 5 to $400 \mathrm{mM}$, L-sorbose from 5 to $500 \mathrm{mM}$, Dsorbose from 10 to $1200 \mathrm{mM}$. $100 \mu \mathrm{L}$ of the assay mixture was preincubated until the complete consumption of ADP present in commercial ATP, followed by addition of $\mathrm{ScrK}_{\text {mitis }}$. Kinetic parameters 
were determined by fitting data by non-linear analysis of initial rates using SigmaPlot version 9.0 (Systat Software).

(vii) ATPase activity of $\mathrm{ScrK}_{\text {mitis }}$. The ATPase activity was determined by using the spectrophotometric coupled assay employing pyruvate kinase and lactate dehydrogenase system. Assay mixture was $0.25 \mathrm{mM} \mathrm{NADH}$, $5 \mathrm{mM} \mathrm{MgCl}_{2}, 5 \mathrm{mM}$ PEP, $1 \mathrm{U}$ PK, $2.3 \mathrm{U}$ LD and $50 \mathrm{mM}$ glycylglycine buffer $\mathrm{pH} 7.5$, and $2.5 \mathrm{mM}$ ATP. $100 \mu \mathrm{L}$ of the assay mixture was preincubated until the complete consumption of ADP present in commercial ATP, followed by addition of $\mathrm{ScrK}_{\text {mitis }}$. Determination of inorganic phosphate in the enzymatic reaction in presence and absence of D-fructose was followed with the colorimetric assay with molybdate. Assay mixture was composed of $50 \mathrm{mM}$ glycylglycine buffer $\mathrm{pH} 7.5$, $5 \mathrm{mM} \mathrm{MgCl} 2,12 \mu \mathrm{g}$ of purified $\mathrm{ScrK}_{\text {mitis }}$, and $2.5 \mathrm{mM}$ of ATP in a final volume of $200 \mu \mathrm{l}$. In the reaction with hexose, $2.5 \mathrm{mM}$ of D-fructose was added. Control was done without adding $\mathrm{ScrK}_{\text {mitis }}$. Aliquot of $50 \mu 1$ was withdrawn at 0,15 , and $30 \mathrm{~min}$ and added to $150 \mu \mathrm{l}$ of buffer $(50 \%$ acetone, 25\% sulfuric acid $5 \mathrm{M}$, and 25\% ammonium molybdate $10 \mathrm{mM}$ ) and $10 \mu \mathrm{l}$ of $1 \mathrm{M}$ citric acid. The absorbance was immediately measured at $355 \mathrm{~nm}$.

\section{HPLC conditions}

HPLC-ELSD analyses were conducted on a Zic-pHilic (Merck, Darmstadt, Germany) column $(4.6 \times 150 \mathrm{~mm} ; 5 \mu \mathrm{m})$ with the following conditions: mixture of $\mathrm{NH}_{4} \mathrm{HCO}_{2} 20 \mathrm{mM} \mathrm{pH} 3.6 / \mathrm{MeCN}$ as eluent with a linear gradient (ratio 20/80 to $60 / 40$ in $15 \mathrm{~min}$, then $60 / 40$ during $5 \mathrm{~min}$ ); flow $0.5 \mathrm{~mL} \mathrm{~min}^{-1}$; temperature $30{ }^{\circ} \mathrm{C}$; injection volume $10 \mu \mathrm{L}$. ELSD parameters $\mathrm{T}_{\text {eva }}=70{ }^{\circ} \mathrm{C} ; \mathrm{T}_{\text {neb }}=40{ }^{\circ} \mathrm{C}$; attenuation $=5$.

Semi-preparative HPLC purifications were conducted on a Zic-Hilic (Merck, Darmstadt, Germany) column $(250 \times 10 \mathrm{~mm}=; 5 \mu \mathrm{m})$ with the following conditions: mixture of $\mathrm{NH}_{4} \mathrm{AcO} 10 \mathrm{mM} \mathrm{pH} 7.7 / \mathrm{MeCN}$ as eluent with a linear gradient (ratio $20 / 80$ to $60 / 40$ in $15 \mathrm{~min}$, then 60/40 during $5 \mathrm{~min}$ ); flow $4 \mathrm{~mL} \min ^{-1}$. ELSD parameters: $\mathrm{T}=70{ }^{\circ} \mathrm{C}$; gain $=5$ : filter $=1 \mathrm{~s}$.

LC-HRMS analyses were performed on a Zic-pHilic (Merck, Darmstadt, Germany) column $(4.6 \times 150 \mathrm{~mm} ; 5 \mu \mathrm{m})$ with the following chromatographic conditions: mixture of $\left(\mathrm{NH}_{4}\right)_{2} \mathrm{CO}_{3} 10 \mathrm{mM} \mathrm{pH} 9.9$ (adjusted with $\mathrm{NH}_{4} \mathrm{OH}$ )/MeCN as eluent with a linear gradient (20/80 for $2 \mathrm{~min}, 20 / 80$ to $60 / 40$ in $20 \mathrm{~min}$, then $60 / 40$ during $8 \mathrm{~min}$ ); flow $0.5 \mathrm{~mL} \mathrm{~min}^{-1}$; temperature $40{ }^{\circ} \mathrm{C}$; injection volume $10 \mu \mathrm{L}$. The Orbitrap Elite mass spectrometer was operated in 
the ESI negative ion mode. For LC-MS and MS/MS (collision induces dissociation, CID) experiments, the resolving power was set at $60000 \mathrm{~m} / \Delta \mathrm{m}$ (full width at half maximum, $\mathrm{FWHM}$ at $\mathrm{m} / \mathrm{z}=400$ ). Ion spray (IS) was set at $-4.2 \mathrm{kV}$ and capillary temperature at $275^{\circ} \mathrm{C}$. Sheath gas and auxiliary gas flow rates were set at 60 and 50 arbitrary units (a. u.), respectively. Mass spectra were acquired over an m/z range from m/z 50 up to $\mathrm{m} / \mathrm{z} 1000$. Raw data were analyzed using the Qual-browser module of Xcalibur version 2.2 (Thermo Fisher Scientific, Waltham, USA).

\section{Biocatalytic synthesis of phosphorylated hexoses}

Conditions $A$ In a Greiner tube $(15 \mathrm{~mL})$ with a screw cap was poured $7.5 \mathrm{~mL}$ of a media containing $50 \mathrm{mM}$ of TRIS $\mathrm{HCl}$ buffer $(375 \mu \mathrm{L}$ of a $1 \mathrm{M}$ solution at $\mathrm{pH} 8.1), 20 \mathrm{mM}$ of hexose ( $150 \mu \mathrm{mol}, 1500 \mu \mathrm{L}$ of a $100 \mathrm{mM}$ solution), $0.5 \mathrm{mM}$ of ATP $\left(3.75 \mu \mathrm{mol}, 37.5 \mu \mathrm{L}\right.$ of a $100 \mathrm{mM}$ solution at $\mathrm{pH}$ 6), $5 \mathrm{mM}$ of $\mathrm{MgCl}_{2}$ (37.5 $\mu \mathrm{mol}, 375 \mu \mathrm{L}$ of a $100 \mathrm{mM}$ solution), $25 \mathrm{mM}$ of PEP $(187.5 \mu \mathrm{mol}, 750 \mu \mathrm{L}$ of a $250 \mathrm{mM}$ solution at $\mathrm{pH} 6), 15 \mathrm{U}$ of $\mathrm{PK}$, and the specified quantity of purified $\mathrm{ScrK}_{\text {mitis }}$. The reaction mixture was stirred at $400 \mathrm{rpm}$ at $30{ }^{\circ} \mathrm{C}$ for the indicated period of time then lyophilized overnight.

Conditions $B$ In a Greiner tube $(50 \mathrm{~mL})$ with a screw cap was poured $15 \mathrm{~mL}$ of a media containing $50 \mathrm{mM}$ of TRIS $\mathrm{HCl}$ buffer $(750 \mu \mathrm{L}$ of a $1 \mathrm{M}$ solution at $\mathrm{pH} 8.1), 10 \mathrm{mM}$ of hexose (150 $\mu \mathrm{mol}, 1500 \mu \mathrm{L}$ of a $100 \mathrm{mM}$ solution), $10 \mathrm{mM}$ of ATP $\left(150 \mu \mathrm{mol}, 1500 \mu \mathrm{L}\right.$ of a $100 \mathrm{mM}$ solution at $\mathrm{pH}$ 6), $5 \mathrm{mM}$ of $\mathrm{MgCl}_{2}$ (75 $\mu \mathrm{mol}, 75 \mu \mathrm{L}$ of a $1 \mathrm{M}$ solution), $25 \mathrm{mM}$ of PEP $(375 \mu \mathrm{mol}, 1500 \mu \mathrm{L}$ of a $250 \mathrm{mM}$ solution at $\mathrm{pH} 6), 150 \mathrm{U}$ of $\mathrm{PK}$, and the specified quantity of purified $\mathrm{ScrK}_{\text {mitis }}$. The reaction mixture was stirred at $400 \mathrm{rpm}$ at $30{ }^{\circ} \mathrm{C}$ for the indicated period of time then freeze-dried overnight.

Purification by ion exchange chromatography The freeze-dried product was dissolved in $\mathrm{NH}_{4} \mathrm{HCO}_{3}$ buffer $0.012 \mathrm{M}$ and purified by ion exchange chromatography using a Dowex (1X8-200-400 mesh, $\left.\mathrm{HCO}_{3}{ }^{-}\right)$resin with a nonlinear gradient of various $\mathrm{NH}_{4} \mathrm{HCO}_{3}$ concentrations: $0.012 \mathrm{M}, 0.03 \mathrm{M}, 0.06 \mathrm{M}$, $0.1 \mathrm{M}, 0.2 \mathrm{M}, 0.3 \mathrm{M}, 0.4 \mathrm{M}$, and $0.6 \mathrm{M}$ (2 vol columns). Fractions containing the compound (HPLC-ELSD analyses $50 \mu \mathrm{L}$ of eluting fractions $+50 \mu \mathrm{L}$ of HPLC eluent $\mathrm{NH}_{4} \mathrm{HCO}_{2} 20 \mathrm{mM} \mathrm{pH} 3.6 / \mathrm{MeCN} 8 / 2$ ) were combined and freeze-dried to afford the phosphorylated hexose. Three successive freeze-drying (solid recovery, dissolution in water) were necessary to ensure the complete removal of buffer.

Purification by semi-preparative HPLC The freeze-dried product was dissolved in HPLC eluent $\mathrm{NH}_{4} \mathrm{AcO} 10 \mathrm{mM} \mathrm{pH}$ 7.7/MeCN 8/2) and injected on 
Zic-Hilic semi-preparative column (injection volumes 2-2.5 mL). Positive fractions (ELSD detection) were combined and freeze-dried to afford the phosphorylated hexose. Three successive freeze-drying (solid recovery, dissolution in water) were necessary to ensure the complete removal of buffer. D-(+)-altrose-6P: The reaction was conducted under conditions A with $0.53 \mathrm{mg}$ of $\mathrm{ScrK}_{\text {mitis }}$ in $10 \mathrm{~h}$ and the product purified by ion-exchange chromatography. Isolated yield: $57 \%$ ( $25 \mathrm{mg}$ of white solid). $\mathrm{NMR}{ }^{13} \mathrm{C}$ was identical to the one found in the literature (Franke et al. 1985). $\mathrm{HRMS} \mathrm{ESI}^{-}, \mathrm{m} / \mathrm{z}$ calcd. for $\left[\mathrm{C}_{6} \mathrm{H}_{12} \mathrm{O}_{9} \mathrm{P}\right]^{-}=259.02244$; found 259.02214.

D-(+)-glucose-6P: The reaction was conducted under conditions A with $0.38 \mathrm{mg}$ of $\mathrm{ScrK}_{\text {mitis }}$ in $8 \mathrm{~h}$ and the product purified by ion-exchange chromatography. Isolated yield: $56 \%$ (22 mg of white solid). Present forms: $\alpha$-pyranose (35\%) and $\beta$-pyranose (65\%). ${ }^{1} \mathrm{H}$ NMR $\left(300 \mathrm{MHz}, \mathrm{D}_{2} \mathrm{O}\right) \delta 5.12(\mathrm{~d}, J=3.63 \mathrm{~Hz}, \mathrm{H} 1 \alpha), 4.54$ (d, $J=7.26 \mathrm{~Hz}, \mathrm{H} 1 \beta), 4.00-3.85$ (m, H6, H2, H4), 3.85-3.76 (m, H5), 3.62 (m, $\mathrm{H} 3$ ), 3.48 (m, H6), 3.45-3.35 (m, H3, H4), 3.61 (dd, $J=9.21$ and $7.99 \mathrm{~Hz}) ;{ }^{13} \mathrm{C}$ NMR (75 MHz, $\left.\mathrm{D}_{2} \mathrm{O}\right) \delta 96.3(\mathrm{C} 1 \beta), 92.4(\mathrm{C} 1 \alpha), 75.6(\mathrm{C} 3 \alpha), 75.4(\mathrm{~d}, J$ $=7.55 \mathrm{~Hz}, \mathrm{C} 5 \beta), 74.4(\mathrm{C} 2 \beta), 72.6(\mathrm{C} 3 \alpha), 71.8(\mathrm{C} 2 \alpha), 71.1(\mathrm{~d}, J=7.71 \mathrm{~Hz}, \mathrm{C} 5 \alpha)$, 69.3 (C4), 63.4 (d, $J=4.48 \mathrm{~Hz}, \mathrm{C} 6 \alpha$ and $\beta$ ) (Fig. S5). HRMS ESI ${ }^{-}, \mathrm{m} / \mathrm{z}$ calcd. for $\left[\mathrm{C}_{6} \mathrm{H}_{12} \mathrm{O}_{9} \mathrm{P}\right]^{-}=259.02244$; found 259.02192 .

D-(+)-mannose-6P: The reaction was conducted under conditions A with $0.04 \mathrm{mg}$ of $\mathrm{ScrK}_{\text {mitis }}$ in $15 \mathrm{~h}$ and the product purified by ion-exchange chromatography. For practical reason, the reaction was carried out overnight but the conversion was $>95 \%$ after $2 \mathrm{~h} 30$ on $100 \mu \mathrm{L}$ scale. Isolated yield: $77 \%$ (30 mg of white solid). Present forms: $\alpha$-pyranose (66\%) and $\beta$-pyranose $(34 \%) .{ }^{1} \mathrm{H}$ NMR (300 MHz, $\mathrm{D}_{2} \mathrm{O}$ ) $\delta 5.03$ (s, H1 $\alpha$ ), under $\mathrm{H}_{2} \mathrm{O}(\mathrm{H} 1 \beta)$, 3.93-3.85 (m, H6), 3.79-

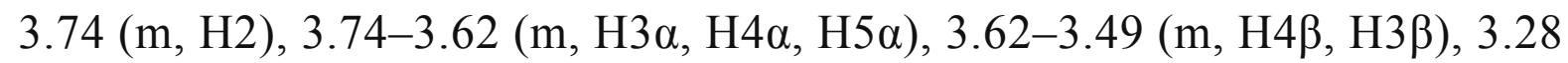
(m, H5 $\beta) ;{ }^{13} \mathrm{C}$ NMR $\left(75 \mathrm{MHz}, \mathrm{D}_{2} \mathrm{O}\right) \delta 94.4(\mathrm{C} 1 \alpha), 94.1(\mathrm{C} 1 \beta), 75.6(\mathrm{~d}, J$ $=7.69 \mathrm{~Hz}, \mathrm{C} 5 \beta), 72.8(\mathrm{C} 3 \beta), 72.0(\mathrm{~d}, J=7.36 \mathrm{~Hz}, \mathrm{C} 5 \alpha), 71.5$ (C2 $\beta), 70.9$ (C2 $\alpha)$, $70.1(\mathrm{C} 3 \alpha), 66.5(\mathrm{C} 4 \alpha), 66.2(\mathrm{C} 4 \beta), 63.1$ (d, $J=4.34 \mathrm{~Hz}, \mathrm{C} 6 \alpha \beta)$ (Fig. S6). HRMS ESI ${ }^{-}, \mathrm{m} / \mathrm{z}$ calcd. for $\left[\mathrm{C}_{6} \mathrm{H}_{12} \mathrm{O}_{9} \mathrm{P}\right]^{-}=259.02244$; found 259.02194 .

D-(+)-talose-6P: The reaction was conducted under conditions A with $0.53 \mathrm{mg}$ of $\mathrm{ScrK}_{\text {mitis }}$ in $7 \mathrm{~h}$ and the product purified by ion-exchange chromatography. Isolated yield: $77 \%$ (30 mg of white solid). Present forms: $\alpha$-pyranose $(41 \%), \beta$ pyranose (36\%), $\alpha$-furanose (13\%) and $\beta$-furanose $(10 \%) .{ }^{1} \mathrm{H}$ NMR $(600 \mathrm{MHz}$, $\left.\mathrm{D}_{2} \mathrm{O}\right) \delta 5.27\left(\mathrm{~d}, J=4.41 \mathrm{~Hz}, \mathrm{H} 1^{\prime} \beta\right), 5.17$ (d, $\left.J=1.62 \mathrm{~Hz}, \mathrm{H} 1 \alpha\right), 5.14\left(\mathrm{~m}, \mathrm{H} 1^{\prime} \alpha\right)$, 4.73 (d, $J=1.08 \mathrm{~Hz}, \mathrm{H} 1 \beta), 4.36$ (m, H3' $\beta$ ), 4.27 (m, H3' $\alpha$ ), 4.10 (m, H5' $\alpha$, H5 $\alpha$ ), 4.01-4.05 (m, H4' $\beta, H 2$ ' $\beta$ ), 3.91 (m, H2' $\alpha, H 3 \alpha$ ), 3.87 (m, H4' $\alpha, H 6 \alpha \beta)$,

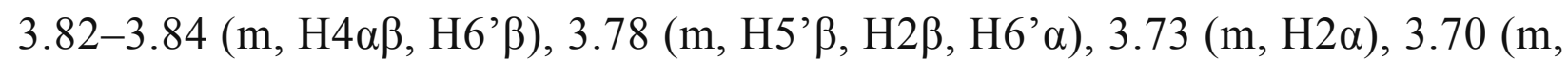




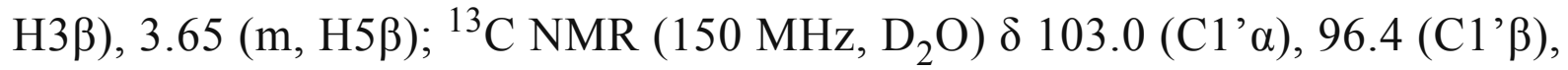

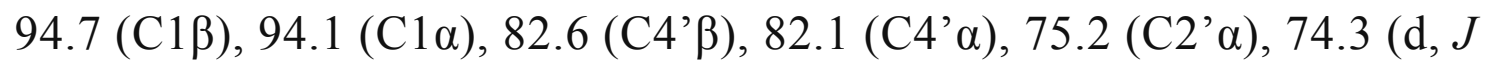
$=7.67 \mathrm{~Hz}, \mathrm{C} 5 \beta), 71.5(\mathrm{C} 2 \beta), 71.0\left(\mathrm{~d}, J=7.12 \mathrm{~Hz}, \mathrm{C} 5^{\prime} \alpha\right), 70.9\left(\mathrm{C}^{\prime}{ }^{\prime} \beta\right), 70.8$ (C2' $\beta), 70.6(\mathrm{C} 2 \alpha), 70.4\left(\mathrm{C}^{\prime}{ }^{\prime} \alpha\right), 70.1$ (d, $\left.J=7.30 \mathrm{~Hz}, \mathrm{C} 5^{\prime} \beta\right), 70.0(\mathrm{~d}, J$ $=7.64 \mathrm{~Hz}, \mathrm{C} 5 \alpha), 69.0(\mathrm{C} 3 \alpha), 68.2(\mathrm{C} 3 \alpha), 68.0(\mathrm{C} 4 \beta), 65.4(\mathrm{~d}, J=4.99 \mathrm{~Hz}$,

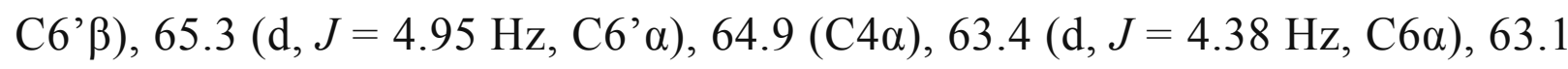
$(\mathrm{d}, J=4.30 \mathrm{~Hz}, \mathrm{C} 6 \beta)$ (Fig. S7). HRMS ESI ${ }^{-}, \mathrm{m} / \mathrm{z}$ calcd. for $\left[\mathrm{C}_{6} \mathrm{H}_{12} \mathrm{O}_{9} \mathrm{P}\right]^{-}=$ 259.02244; found 259.02211.

D-psicose-6P: The reaction was conducted under conditions B with $3 \mathrm{mg}$ of ScrK $_{\text {mitis }}$ in 4 days and the product purified by ion-exchange chromatography. Isolated yield: $51 \%$ (20 mg of white solid). Present forms: $\alpha$-furanose $(35 \%)$ and $\beta$-furanose (65\%). ${ }^{1} \mathrm{H}$ NMR (300 MHz, $\left.\mathrm{D}_{2} \mathrm{O}\right) \delta 4.37-4.29$ (m, H4 $\left.\alpha \beta\right), 4.19-4.04$ (m, H3 $\alpha \beta$ ), 4.00-3.66 (m, H5 $\alpha \beta, \mathrm{H} 6 \alpha \beta$ ), 3.55-3.45 (m, H1 $\alpha \beta$ ) (Fig. S8); NMR ${ }^{13} \mathrm{C}$ was identical to the one found in the literature (Koerner Jr et al. 1980). HRMS ESI ${ }^{-}, \mathrm{m} / \mathrm{z}$ calcd. for $\left[\mathrm{C}_{6} \mathrm{H}_{12} \mathrm{O}_{9} \mathrm{P}\right]^{-}=259.02244$; found 259.02206 .

D-fructose-6P: The reaction was conducted under conditions A with $0.04 \mathrm{mg}$ of $\mathrm{ScrK}_{\text {mitis }}$ in $30 \mathrm{~min}$ and the product purified by semi-preparative HPLC. Isolated yield: $72 \%$ (28 mg of white solid). Present forms: $\alpha$-furanose $(25 \%)$ and $\beta$ furanose (75\%); ${ }^{13} \mathrm{C}$ NMR was identical to those found in the literature (Sánchez-Moreno et al. 2012).

L-sorbose-5P: The reaction was conducted under conditions A with $1.5 \mathrm{mg}$ of $\mathrm{ScrK}_{\text {mitis }}$ in $24 \mathrm{~h}$ and the product purified by semi-preparative HPLC. Isolated yield: $67 \%$ (26 mg of white solid). Present form: $\alpha$-pyranose (>95\%). ${ }^{1} \mathrm{H}$ NMR $\left(500 \mathrm{MHz}, \mathrm{D}_{2} \mathrm{O}\right) \delta 3.82(\mathrm{~m}, \mathrm{H} 5), 3.71$ (dd, $J=11.08$ and $\left.5.38 \mathrm{~Hz}, \mathrm{H} 6 \mathrm{a}\right), 3.62$ (t, $J=9.15 \mathrm{~Hz}, \mathrm{H} 4), 3.55-3.49$ (m, H1a, H6b), 3.39 (d, $J=9.50 \mathrm{~Hz}, \mathrm{H} 3$ ), 3.36 (d, $J$ $=11.75 \mathrm{~Hz}, \mathrm{H} 1 \mathrm{~b}) ;{ }^{13} \mathrm{C} \mathrm{NMR}\left(125 \mathrm{MHz}, \mathrm{D}_{2} \mathrm{O}\right) \delta 97.5(\mathrm{C} 2), 73.5(\mathrm{~d}, J=$ $3.09 \mathrm{~Hz}, \mathrm{C} 4), 72.4$ (d, $J=4.40 \mathrm{~Hz}, \mathrm{C} 5), 70.4$ (C3), 63.6 (C1), 60.9 (d, $J=$ $2.93 \mathrm{~Hz}, \mathrm{C6}$ ) (Fig. S9). HRMS ESI-, m/z calcd. for [C6H12O9P]- = 259.02244; found 259.02208 .

D-tagatose-6P: The reaction was conducted under conditions A with $0.38 \mathrm{mg}$ of $\mathrm{ScrK}_{\text {mitis }}$ in $2 \mathrm{~h}$ and the product purified by semi-preparative HPLC. Isolated yield: $51 \%$ (20 mg of white solid). Present forms: $\alpha$-furanose $(25 \%)$ and $\beta$ furanose (75\%). ${ }^{1} \mathrm{H}$ NMR (300 MHz, $\left.\mathrm{D}_{2} \mathrm{O}\right) \delta 4.37-4.30(\mathrm{~m}, \mathrm{H} 4 \alpha \beta), 4.20(\mathrm{~m}$, $\mathrm{H} 3 \alpha \beta), 4.12-3.82$ (m, H5 $\alpha \beta, \mathrm{H} 6 \alpha \beta), 3.61$ (d, $J=4.29 \mathrm{~Hz}, \mathrm{H} 1 \alpha), 3.51$ (d, $J=$ $3.99 \mathrm{~Hz}, \mathrm{H} 1 \beta$ ) (Fig. S10); ${ }^{13} \mathrm{C}$ NMR was identical to the one found in the literature (Koerner Jr et al. 1980). HRMS ESI-, m/z calcd. for [C6H12O9P]- = 259.02244; found 259.02211. 


\section{Results}

\section{Screening of a kinase collection}

A kinase collection was built by a sequence driven approach (Vergne-Vaxelaire et al. 2013) using the fructokinase FrK from Zymomonas mobilis (Weisser et al. 1996; Zembrzuski et al. 1992) as reference. Frk is the unique ROK-type fructokinase (Uniprot ID: Q03417) with enzymatic characterization done on purified enzyme (Table S4) showing moderate activity toward D-mannose in addition to D-fructose. Since little is known about the substrate scope of ROKtype fructokinase enzymes, thus, exploration of their substrate specificity toward sugars is of great interest.

A collection of 90 proteins representative of the diversity among bacteria was selected from the UniProt database. From these candidates, 65 corresponding genes were successfully cloned with a poly-histidine tag in an expression vector (Table S1 and Table S2). After overexpression of recombinant genes in Escherichia coli strain BL21, cells were lyzed and proteins purified by nickel affinity chromatography in 96 microwells (Fig. S1). The 63 successfully purified enzymes were then screened against 4 ketohexoses (D-fructose, D-tagatose, Dsorbose, and D-psicose) and 3 aldohexoses (D-glucose, D-mannose, and Dgalactose). The kinase activity of each candidate protein was assessed in 384microplates by spectrophotometrically monitoring at $340 \mathrm{~nm}$, the consumption of the NADH using the coupled generic assay employing pyruvate kinase, and lactate dehydrogenase (Scheme S1). Sixty-one enzymes very diverse in term of protein sequence (Fig. S11) were found to catalyze the formation of at least one phosphorylated hexose. In our conditions, no activity could be detected toward D-galactose. Two enzymes weakly purified showed no activity against any hexose (no activity could be detected for $\mathrm{C} 5$ and $\mathrm{C} 4$ monosaccharides too, data not shown). These kinases could be classified in two groups according to their substrate specificity: a small group, gathering proteins active toward D-glucose and a group, bringing together most of the proteins (55 out of 61), exhibiting, at least, activities toward both D-mannose and D-fructose (Fig. 1a). Noteworthy among them, 42 kinases exhibited such a high activity $(>50 \mathrm{U} / \mathrm{mg}$ ) toward Dmannose and D-fructose that it was not possible to determine their specific activity in the generic screening conditions. Moreover, most of these kinases were also active toward D-tagatose and some of them had low activity toward Lsorbose or D-psicose (Table S3). It may be noted that, in our conditions, most of the fructo- and glucokinases were weakly active toward D-glucose and Dfructose, respectively.

\section{Fig. 1}


Phylogenetic tree with the 61 ROK-type kinases compared to known ROK-type proteins. Activity of known ROK-type sugar kinases from the inventory (Table S4 and Table S5) are noted with gene name put in parenthesis next to Uniprot identifier. Their activities toward substrates described in the corresponding publications have been symbolized qualitatively with a star and mostly have not been tested in this study. Experimentally data from this study are symbolized by squares whose size is categorized according to specific activities (Table S3 and Table S6). Frk used as reference set for the sequence driven approach is written in blue. The most promiscuous and efficient enzyme in our conditions of screening is written in red. Dotted rectangle gathers known ROK-type repressors whereas green rectangle gathers fructokinases. a Activity toward D-fructose (F), L-sorbose (S), D-tagatose (T), D-psicose (P), D-glucose (G), D-mannose (M). b Activity toward D-cellobiose (C) and $N$-acetyl-D-glucosamine (N). Bootstrap values superior to 80 have been noted on the branch of the phylogenetic tree 


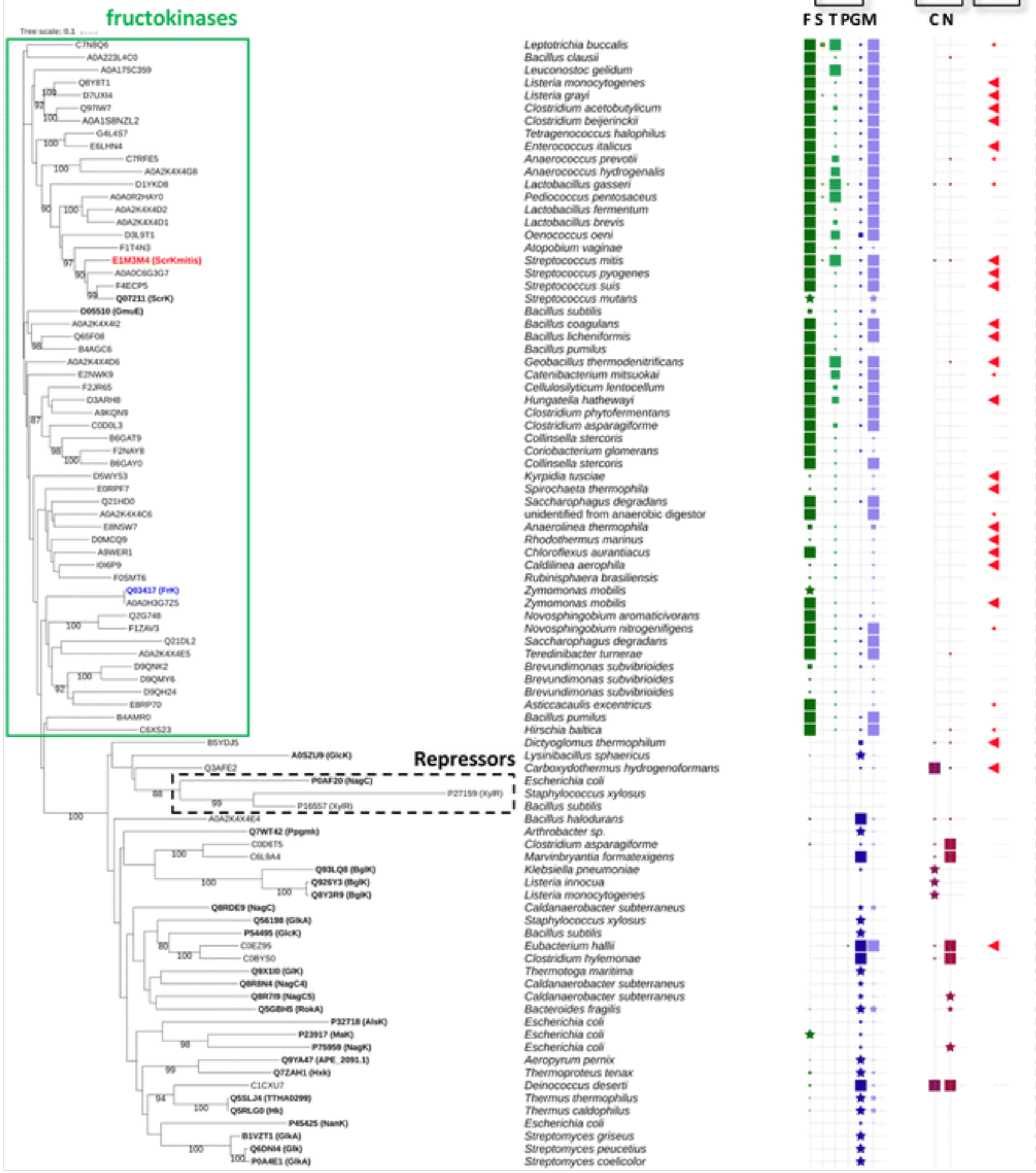

\section{ROK-type sugar kinases}

Since Frk from Z. mobilis used as reference protein belongs to ROK-type family, we investigated the ROK conserved sequence features (Conejo et al. 2010) among the 61 kinases. From a literature survey, a careful inventory of sugar kinases was done. For each of these kinases, the conserved Interpro domain IPR000600 specific of ROK family was searched allowing the identification of 29 ROK-type sugar kinases related to a publication but not always biochemically 
characterized. The resulting glucokinases, allokinases, ATP-glucomannokinases, $\beta$-glucoside kinases, $N$-acetyl-D-glucosamine kinases, and fructokinases (listed in Table S4 and Table S5) were added to the multiple sequence alignment of the 61 kinases.

First, the two glycine-rich ROK consensus motifs corresponding to ExGH and a Zn-binding motif (Conejo et al. 2010) were found in all experimentally tested kinases of this study confirming their belonging to ROK family (Fig. S12). Nevertheless, we observed that the ATP/ $\mathrm{Mg}^{2+}$ binding site (DXGXT), described as common to ROK-type kinases (Holmes et al. 1993) was shared as expected by glucokinases, allokinases, ATP-glucomannokinases, $\beta$-glucoside kinases, and $N$ acetyl-D-glucosamine kinases but not by fructokinases (Fig. S13). For this subfamily, glutamate is always substituted by aspartate in their ATP $/ \mathrm{Mg}^{2+}$ binding site (EXGXT) confirming the predictions based on structural analysis (Conejo et al. 2010). In addition, we also observed that the Thr/Pro/Lys triad was conserved among the fructokinases and absent within other ROK-type sugar kinases (Fig. S14) partitioning clearly these families, corroborating the hypothesis formulated by (Conejo et al. 2010).

To evaluate the distribution of these 61 sugar kinases among the whole ROK family, our experimental data were mapped on a phylogenetic tree (Fig. 1a) built with the 61 characterized kinases of this study supplemented with the known ROK-type kinases (see the inventory in Table S4 and Table S5) and ROK-type repressors (two XylR (Kreuzer et al. 1989; Sizemore et al. 1991) and NagC (Plumbridge 2001)). Glucokinases, including the ones found in this study, are grouped together with the ROK-type repressors, forming a group significantly distinct to the one of the fructokinases. Actually, the 4 known fructokinases (ScrK(Sato et al. 1993), FrK (Scopes et al. 1985) GmuE (Nocek et al. 2011) and Mak (Sproul et al. 2001)) and the experimentally proved fructokinases are not significantly phylogenetically related to other ROK-type sugar proteins. Notably, glucokinases are found clusterized with kinases described to be $\beta$-glucoside kinases BglK (Thompson et al. 1992) and N-acetyl-glucosamine kinases NagK (Uehara and Park 2004). In order to test the ability of the sugar kinase collection to phosphorylate glucose derivatives, ATP-dependent activities for phosphorylation of D-cellobiose and $N$-acetyl-D-glucosamine were assayed (Table S6 and Fig. 1b). The results showed that only two glucokinases were active toward D-cellobiose whereas 5 glucokinases were active toward $N$-acetylD-glucosamine. In our conditions, no fructokinase was found significantly active toward these derivatives.

Guided by potential biotechnological applications of these promiscuous 61 kinases for the synthesis of rare sugars, enzyme thermotolerance was assessed. 
Enzyme thermotolerance was determined by incubation of cell crude extract in 96-microplates at $70{ }^{\circ} \mathrm{C}$ for $20 \mathrm{~min}$. Thirty-six percent of expressed enzymes were significantly visible to the eye on SDS gel, suggesting their thermotolerance (Fig. S2). ATP-dependent activities for phosphorylation of Dfructose, D-tagatose, and D-glucose were determined as previously described (Fig. S4). Twenty-three kinases showed no significant loss of activity (Fig. 1c and Table S7). From these thermotolerant promiscuous kinases, one enzyme from Streptococcus mitis (Uniprot id: E1M3M4) was selected for its ability to phosphorylate most of the tested hexoses.

\section{Purification and biochemical properties of E1M3 $\mathrm{M}_{4}$ from Streptococcus mitis NCTC 12261 (DSM 12643)}

E1M3M4 shares $72 \%$ of identity with the fructokinase ScrK from Streptococcus

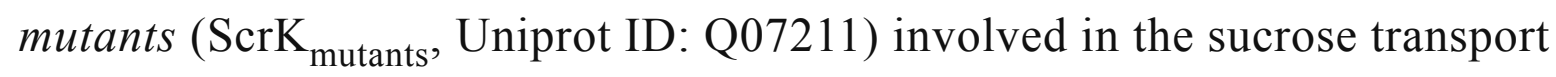
through a phosphoenolpyruvate-dependent phosphotransferase system (PTS) (Sato et al. 1993). An apparent $\mathrm{V}_{\text {max }}$ for D-fructose of $20.0 \mathrm{pmol} / \mathrm{min} / \mathrm{mg}$ of protein was reported on cell crude extract by (Sato et al. 1993). In addition, the genes encoding for E1M3M4 and $\mathrm{ScrK}_{\text {mutants }}$ share a similar genomic context (Fig. S15) including a predicted sucrose enzyme II (ScrA) and sucrose-6P hydrolase (ScrB) (Sato et al. 1989) usually involved in disaccharide uptake by phosphoenolpyruvate-dependent phosphotransferase system (PTS system) (Postma et al. 1993). Based on these features, E1M3M4 was named ScrK mitis $_{\text {. }}$ Purified ScrK $_{\text {mitis }}$ was obtained by nickel affinity chromatography purification (47.5 mg from $100 \mathrm{~mL}$ of culture). SDS gel showed a single band corresponding to a calculated molecular mass of $32.8 \mathrm{kDa}$ (Fig. S3). Size exclusion chromatography indicated that $\mathrm{ScrK}_{\text {mitis }}$ is a homodimer, as previously reported for the fructokinase of Zymomonas mobilis $\left(\mathrm{FrK}_{\text {mobilis }}\right)$ (Scopes et al. 1985). Biochemical properties of this purified enzyme were as follows.

(i) Substrate specificity

To determine the substrate range of $\mathrm{ScrK}_{\text {mitis }}$, specific activities were calculated for all hexoketoses and hexoaldoses (Table 1) in the D- and L- series and some

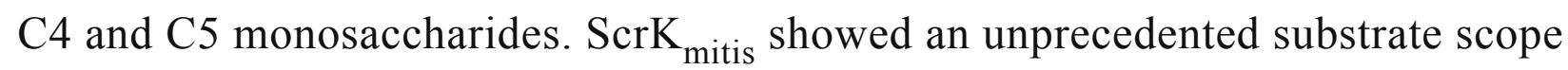
with high activities toward D-fructose $\left(287 \mathrm{U} \mathrm{mg}^{-1}\right)$ and D-mannose (395 $\mathrm{U} \mathrm{mg}^{-1}$ ) (Table 1, entry 10 and 4). Significant specific activities (> $0.1 \mathrm{U} \mathrm{mg}^{-1}$ of protein) were measured for all natural hexoses except D-galactose. ScrK $_{\text {mitis }}$ phosphorylated also rare sugars, like for D-psicose, D-allose, and Dgulose, with low specific activities $\left(<0.1 \mathrm{U} \mathrm{mg}^{-1}\right.$ of protein) (Table 1, entries 9, 1 , and 5 respectively). Unnatural monosaccharides were also phosphorylated, Daltrose with high specific activities (105 $\mathrm{U} \mathrm{mg}^{-1}$, Table 1 entry 2$)$ and D-talose 
and D-idose with lower activities $\left(4.7\right.$ and $<0.1 \mathrm{U} \mathrm{mg}^{-1}$ respectively, Table 1 entries 8 and 6). Some L-monosaccharides were also phosphorylated such as Lsorbose and L-altrose (Table 1, entries 11 and 2, respectively) even if the activity was generally higher for D-configuration than L-configuration. Moreover, some $\mathrm{C} 4$ and $\mathrm{C} 5$ monosaccharides revealed to be also substrates, notably D-lyxose $\left(0.16 \mathrm{U} \mathrm{mg}^{-1}\right)$. Traces of activity could be detected for D-erythrose $\left(0.04 \mathrm{U} \mathrm{mg}^{-1}\right)$ and L-erythrulose $\left(0.018 \mathrm{U} \mathrm{mg}^{-1}\right)$. In our reaction conditions Dribose, D- and L-arabinose, D-xylose, D-xylulose, L-erythrose, D- and L-threose, Derythrulose were not substrates.

\section{Table 1}

Specific activities of purified ScrK $_{\text {mitis }}$ toward hexoses (D- and L-series)

\begin{tabular}{|c|c|c|c|}
\hline \multirow[t]{2}{*}{ Entry } & \multirow[t]{2}{*}{ Substrates } & \multicolumn{2}{|c|}{$\begin{array}{l}\text { Specific activity } \\
\text { (U/mg of enzyme) }\end{array}$} \\
\hline & & $\mathrm{D}$ & $\mathrm{L}$ \\
\hline \multicolumn{4}{|c|}{ C6-Aldose substrates } \\
\hline 1 & Allose & 0.1 & 0.4 \\
\hline 2 & Altrose & 105 & 1 \\
\hline 3 & Glucose & 4.8 & nd \\
\hline 4 & Mannose & 395 & $<0.1$ \\
\hline 5 & Gulose & $<0.1$ & $<0.1$ \\
\hline 6 & Idose & $<0.1$ & $<0.1$ \\
\hline 7 & Galactose & 0 & $<0.1$ \\
\hline 8 & Talose & 4.7 & $<0.1$ \\
\hline \multicolumn{4}{|c|}{ c6-Ketose substrates } \\
\hline 9 & Psicose & $<0.1$ & 0.24 \\
\hline 10 & Fructose & 287 & $<0.1$ \\
\hline 11 & Sorbose & 0.4 & 0.65 \\
\hline 12 & Tagatose & 15 & 0.15 \\
\hline \multicolumn{4}{|c|}{$\begin{array}{l}\text { One unit }(\mathrm{U}) \text { of enzyme activity was defined as the amount of enzyme that catalyzed } \\
\text { the conversion of } 1 \mu \mathrm{M} \text { of substrate per minute }\end{array}$} \\
\hline nd not dete & & & \\
\hline
\end{tabular}

In addition, $\mathrm{ScrK}_{\text {mitis }}$ showed a low ATPase activity in our conditions $\left(K_{\mathrm{M}}=\right.$ $\left.0.9 \mathrm{mM} ; k_{c a t} / K_{\mathrm{M}}=32 \mathrm{~s}^{-1} \mathrm{M}^{-1}\right)$. Nevertheless, in presence of fructose, no release 
of Pi was detected using acidified ammonium molybdate assay (Heinonen and Lahti 1981) (Fig. S16). To our knowledge, this feature was only described for sugar kinases from yeast (Rother et al. 2017; Rudolph and Fromm 1971).

(ii) Thermotolerance

To confirm the thermotolerance previously observed in 96-microwells, measurement of enzyme activity after heat treatment was carried out. Heat treatment cell free extract of $\mathrm{ScrK}_{\text {mitis }}$ at $70{ }^{\circ} \mathrm{C}$ for 20 min was then done. Recovered protein mass ( $42.0 \mathrm{mg}$ from $100 \mathrm{~mL}$ of culture) was similar to the one obtained by nickel affinity chromatography purification. SDS gel showed only one band of $32.8 \mathrm{kDa}$ corresponding to the expected mass of $\mathrm{ScrK}_{\text {mitis }}$ (Fig. S3b) showing that heat treatment can be used as a quick and easy purification method. Specific activities were then measured for D-fructose, D-mannose, and D-glucose, and compared to ones obtained with $\mathrm{ScrK}_{\text {mitis }}$ purified by nickel affinity chromatography. Loss of activity was estimated between 20 and 30\% (Table S8).

(iii) $\mathrm{pH}$ and temperature activity profiles

Several parameters influencing the enzymatic activity have been tested. In order to define the optimal $\mathrm{pH}$, specific activities toward $\mathrm{D}$-fructose were determined using various buffer and $\mathrm{pH}$ (Fig. 2). Buffers ranging from $\mathrm{pH} 4.5$ to $\mathrm{pH} 12.4$ were used. $\mathrm{ScrK}_{\text {mitis }}$ displayed a relatively broad $\mathrm{pH}$ profile with a maximum activity at basic $\mathrm{pH}$ (7 to 10). Activities dropped at $\mathrm{pH}$ values below 5.9 and above 11.0.

\section{Fig. 2}

Effect of $\mathrm{pH}$ on the fructokinase activity of $\mathrm{ScrK}_{\text {mitis }}$. Error bars represent the standard deviation of three independent experiments 


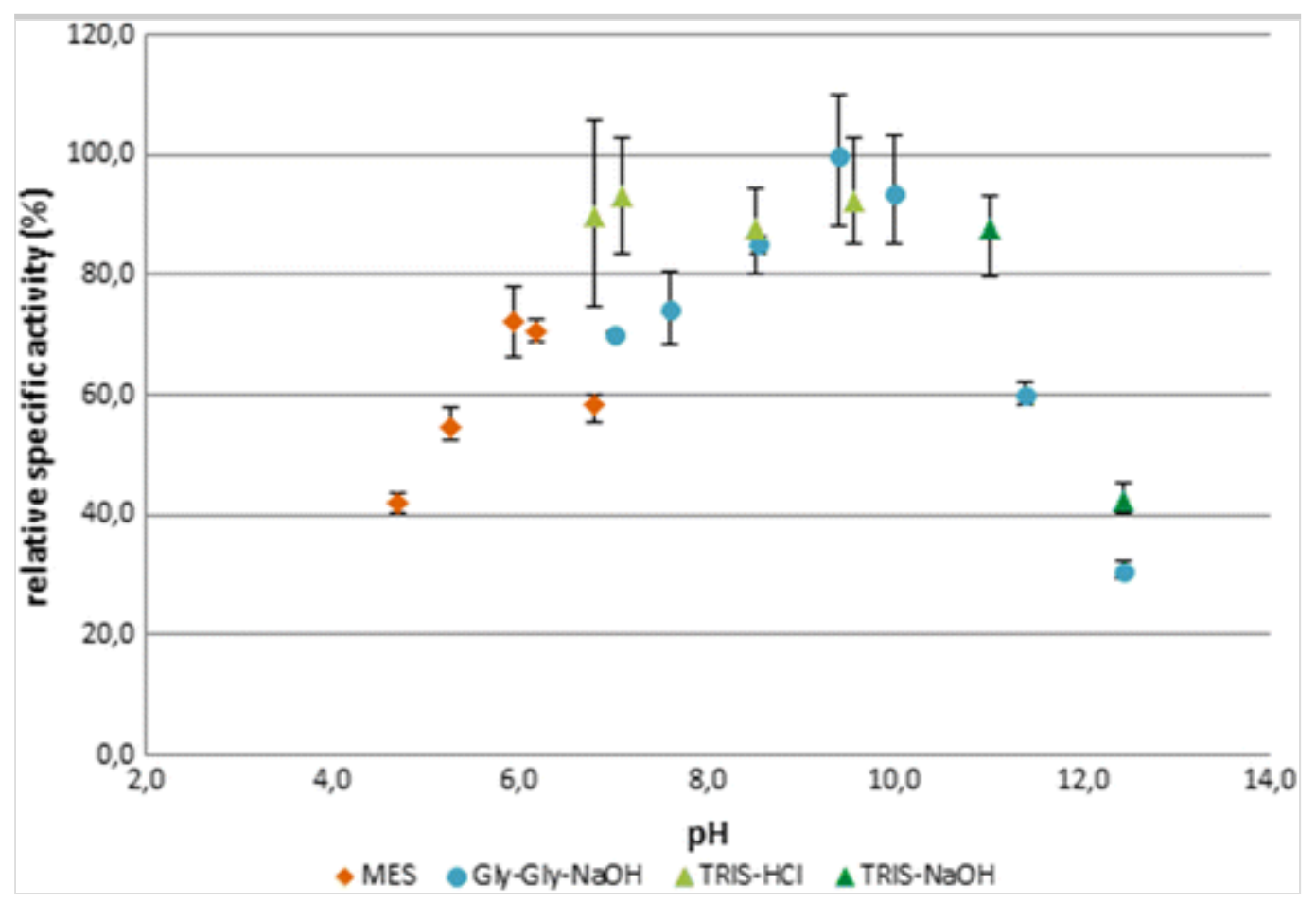

Unlike ROK glucokinases, no ROK fructokinase has been shown to be active at high temperatures. Since $\mathrm{ScrK}_{\text {mitis }}$ from the mesophilic bacteria Streptococcus mitis was shown to be thermotolerant, we investigated its temperature activity profile (Fig. 3). Assays were carried out toward D-fructose at various temperatures ranging from 15 to $80{ }^{\circ} \mathrm{C}$. Its maximum activity was found at approximately $55^{\circ} \mathrm{C}$, leading to an about two-fold higher activity compared to incubation at room temperature. The activity decreased rapidly at temperature higher than $70{ }^{\circ} \mathrm{C}$ but high activity $(>85 \%)$ was maintained within a relatively wide temperature range of $40-70{ }^{\circ} \mathrm{C}$.

(iv) Metal ion requirement

\section{Fig. 3}

Temperature activity profile of $\mathrm{ScrK}_{\text {mitis. }}$ Error bars represent the standard deviation of three independent experiments 


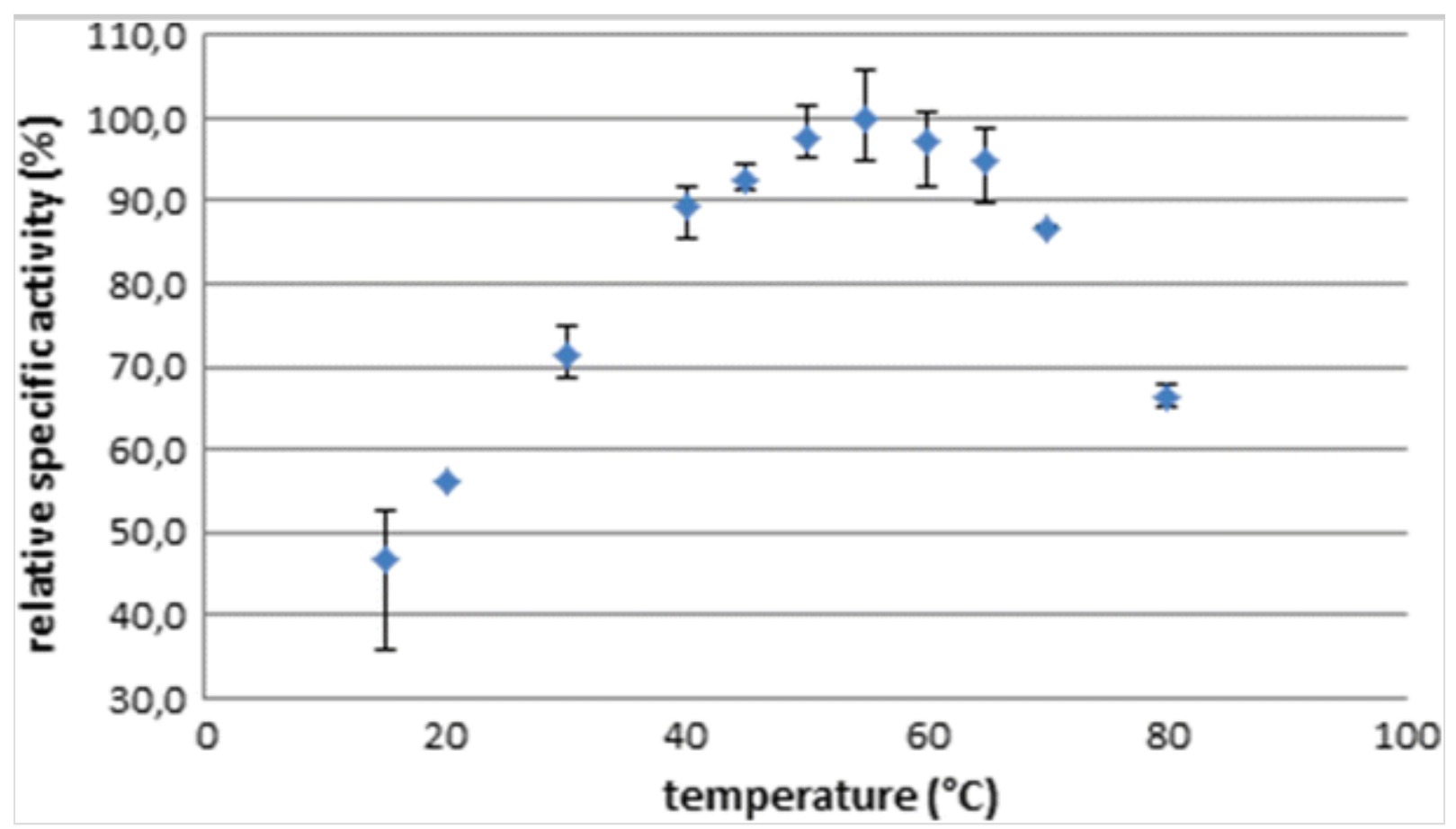

ScrK $_{\text {mitis }}$ metal ion activity profile (Fig. 4) conducted with $5 \mathrm{mM}$ of cation and D-fructose as substrate indicated a maximal activity with $\mathrm{Mg}^{2+}$ and $\mathrm{Co}^{2+}$ (relative activity 100 and $98.5 \%$, respectively). The activity remained important with $\mathrm{Mn}^{2+}(79.3 \%)$ but dropped drastically in the presence of $\mathrm{Zn}^{2+}, \mathrm{Ca}^{2+}$, or $\mathrm{Ni}^{2+}$ (24.1, 12.9, and $6.5 \%$, respectively). No activity was detected in presence of $5 \mathrm{mM}$ of $\mathrm{Cu}^{2+}$ or in absence of metal cation.

Fig. 4

Effect of the metal ions on the specific activity of $\mathrm{ScrK}_{\text {mitis. }}$ Error bars represent the standard deviation of three independent experiments

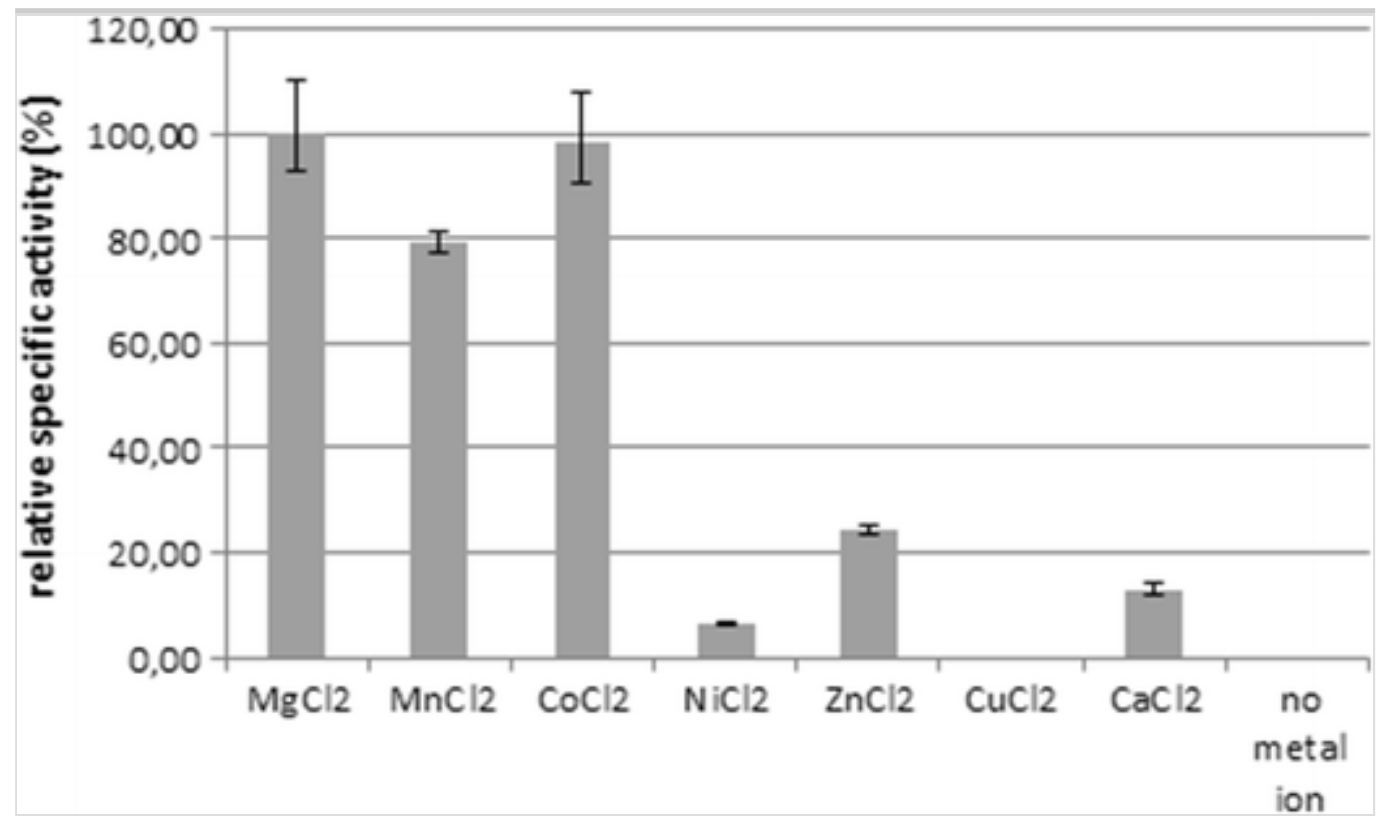




\section{Kinetic constants}

In the course of our characterization study, kinetic constants were determined for 8 hexoses for which specific activities were found higher than $0.1 \mathrm{U} \mathrm{mg}^{-1}$ of enzyme (Table 1). Lowest $K_{\mathrm{M}}$ were measured for D-mannose and D-fructose with respective values of 150 and $730 \mu \mathrm{M}$ compared, for example, to $23 \mathrm{mM}$ for $\mathrm{D}-$

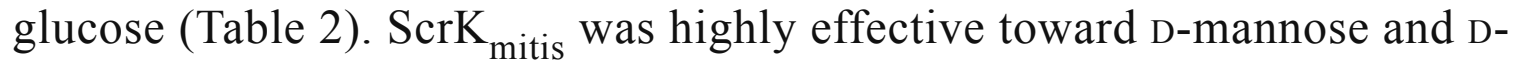
fructose $\left(k_{c a t} / K_{\mathrm{M}}=1.510^{6}\right.$ and $2.710^{5}$, respectively, Table 2 , entries 2 and 3 ). An about 10-fold lower catalytic efficiency was still recorded for the transformation of the isomer D-altrose (Table 2, entry 4) while it was 1000-fold lower for D-tagatose, D-talose and D-glucose (Table 2, entries 5-7) (Fig. 5).

\section{Table 2}

Kinetic parameters of $\mathrm{ScrK}_{\text {mitis }}$

\begin{tabular}{|l|l|l|l|l|}
\hline Entry & \multicolumn{1}{|c|}{ Substrate } & $\boldsymbol{k}_{\text {cat }}\left(\mathbf{s}^{-\mathbf{1}}\right)$ & \multicolumn{1}{|c|}{$\boldsymbol{K}_{\mathbf{M}}(\boldsymbol{\mu M})$} & \multicolumn{1}{|c|}{$\boldsymbol{k}_{\text {cat }} / \mathbf{K}_{\mathbf{M}}\left(\mathbf{s}^{-\mathbf{1}} \mathbf{M}^{-\mathbf{1}}\right)$} \\
\hline 1 & ATP & $186 \pm 2$ & $45.0 \pm 2.8$ & $4.110^{6}$ \\
\hline 2 & D-mannose & $223 \pm 10$ & $150.0 \pm 29.0$ & $1.510^{6}$ \\
\hline 3 & D-fructose & $193 \pm 10$ & $730.0 \pm 63.0$ & $2.710^{5}$ \\
\hline 4 & D-altrose & $163 \pm 6$ & $15.010^{3} \pm 1.610^{3}$ & $1.110^{4}$ \\
\hline 5 & D-tagatose & $45 \pm 1.3$ & $13.010^{3} \pm 1.510^{3}$ & $3.510^{2}$ \\
\hline 6 & D-talose & $9.5 \pm 0.3$ & $28.010^{3} \pm 3.310^{3}$ & $3.410^{2}$ \\
\hline 7 & D-glucose & $3.3 \pm 0.1$ & $23.010^{3} \pm 2.810^{3}$ & $1.410^{2}$ \\
\hline 8 & L-sorbose & $2.7 \pm 0.1$ & $46.910^{3} \pm 3.810^{3}$ & 57 \\
\hline 9 & D-sorbose & $1.4 \pm 0.1$ & $168.010^{3} \pm 16.510^{3}$ & 9 \\
\hline
\end{tabular}

\section{Fig. 5}

Phosphorylated hexoses biocatalytically synthetized in this study 


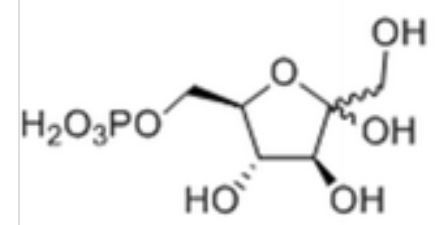

D-fructose-6P furanose form $(\alpha / \beta)$<smiles>O=P(O)(O)OC[C@H]1O[C@H](O)[C@H](O)[C@@H](O)[C@@H]1O</smiles>

D-altrose-6P pyranose form $(\alpha / \beta)$<smiles>O=P(O)(O)OC[C@H]1O[C@](O)(CO)[C@H](O)[C@@H]1O</smiles>

D-psicose-6P furanose form $(\alpha / \beta)$<smiles>OC[C@]1(O)OC[C@@H]([18OH])[C@@H](O)[C@H]1O</smiles>

L-sorbose-5P pyranose form $(\alpha / \beta)$

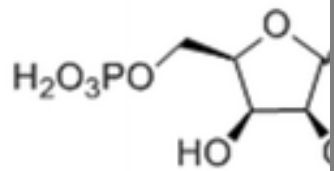

D-tagatos furanose fort<smiles>O=P(O)(O)OC[C@H]1O[C@H](O)[C@H](O)[C@@H](O)[C@@H]1O</smiles>

D-glucose-6P

D-altrose-6P furanose form $(\alpha / \beta)$<smiles>O=P(O)(O)OC[C@H]1O[C@H](O)[C@H](O)[C@@H](O)[C@@H]1O</smiles>

D-talose-6P pyranose form $(\alpha / \beta)$<smiles>O=[Po](O)C[C@H](O)[C@@H]1O[C@H](O)[C@H](O)[C@@H]1O</smiles>

D-talose-6P furanose form $(\alpha / \beta)$<smiles>O=P(O)(O)OC[C@H]1O[C@H](O)[C@H](O)[C@@H](O)[C@@H]1O</smiles>

D-mannose-6P pyranose form $(\alpha / \beta)$

\section{Biocatalytic synthesis and characterization of phosphorylated hexoses}

To evaluate the $\mathrm{ScrK}_{\text {mitis }}$ ability for the synthesis of phosphorylated hexoses, biocatalytic transformations of a representative panel of substrates were carried out on a $150-\mu \mathrm{mol}$ scale. In a first step, the biocatalytic synthesis was developed on D-fructose. Polyphosphate (from 1 to 10 equivalents) was evaluated as low cost phosphate donor but no conversion could be detected. Therefore, ATP was maintained using a recycling system. Regeneration of $0.5 \mathrm{mM}$ of ATP by the $\mathrm{PEP} /$ pyruvate kinase system led to a total conversion of $20 \mathrm{mM}$ of substrate in $30 \mathrm{~min}$ with only $0.005 \mathrm{mg} / \mathrm{mL}$ of enzyme. In the absence of the regeneration system, the conversion reached only $7 \%$ in $3 \mathrm{~h}$ with one equivalent of ATP or $85 \%$ in 5 days with regular addition of ATP ( 1 eq in total) (data not shown). The corresponding phosphorylated product was purified by semi-preparative HPLC in $72 \%$ yield. The same reaction conditions, with the appropriate amount of enzyme $\mathrm{ScrK}_{\text {mitis }}$, were applied to the synthesis of the phosphorylated derivatives of aldoses D-altrose, D-glucose, D-mannose, D-talose and ketoses Dpsicose, L-sorbose, and D-tagatose. All the phosphorylated products were formed in 30 min to $30 \mathrm{~h}$ with at least $90 \%$ conversion except for D-psicose for which 4 days with $10 \mathrm{mM}$ of ATP were required to reach $70 \%$ conversion (Table 3 ). 
The corresponding phosphorylated products were purified by semi-preparative HPLC or ion-exchange chromatography in 51 to $77 \%$ yield.

Table 3

Biocatalytic phosphorylation of some hexoses by $\mathrm{ScrK}_{\text {mitis }}$

\begin{tabular}{|c|c|c|c|c|c|c|c|}
\hline \multirow[t]{2}{*}{ Entry } & \multirow[t]{2}{*}{ Products } & \multirow{2}{*}{$\begin{array}{l}\text { Conversion } \\
\text { (\%) (time) }\end{array}$} & \multirow{2}{*}{$\begin{array}{c}\text { Isolated } \\
\text { yield } \\
(\%)\end{array}$} & \multicolumn{4}{|c|}{ Present forms $(\%)^{\mathrm{a}}$} \\
\hline & & & & $\begin{array}{l}\alpha- \\
\text { Furanose }\end{array}$ & $\begin{array}{l}\beta \text { - } \\
\text { Furanose }\end{array}$ & $\begin{array}{l}\alpha- \\
\text { Pyranose }\end{array}$ & $\begin{array}{l}\beta- \\
\text { Pyrano: }\end{array}$ \\
\hline 1 & $\begin{array}{l}\mathrm{D}- \\
\text { fructose- } \\
6 \mathrm{P}\end{array}$ & $\begin{array}{l}>99 \\
(30 \mathrm{~min})\end{array}$ & 72 & 21 & 79 & nd & nd \\
\hline 2 & $\begin{array}{l}\text { D- } \\
\text { psicose- } \\
6 \mathrm{P}\end{array}$ & 70 (4 days) & 51 & 35 & 65 & nd & nd \\
\hline 3 & $\begin{array}{l}\text { L- } \\
\text { sorbose- } \\
5 \mathrm{P}\end{array}$ & $>99(24 \mathrm{~h})$ & 67 & nd & nd & $>95$ & nd \\
\hline 4 & $\begin{array}{l}\mathrm{D}- \\
\text { altrose- } \\
6 \mathrm{P}\end{array}$ & $90(10 \mathrm{~h})$ & 57 & 15 & 11 & 31 & 43 \\
\hline 5 & $\begin{array}{l}\mathrm{D}- \\
\text { tagatose- } \\
6 \mathrm{P}\end{array}$ & $>99(2 \mathrm{~h})$ & 51 & 25 & 75 & nd & nd \\
\hline 6 & $\begin{array}{l}\text { D- } \\
\text { glucose- } \\
6 \mathrm{P}\end{array}$ & $>99(8 \mathrm{~h})$ & 56 & nd & nd & 35 & 65 \\
\hline 7 & $\begin{array}{l}\mathrm{D}- \\
\text { mannose- } \\
6 \mathrm{P}\end{array}$ & $>99(15 \mathrm{~h})$ & 77 & nd & nd & 66 & 34 \\
\hline 8 & $\begin{array}{l}\text { D-talose- } \\
6 \mathrm{P}\end{array}$ & $95(7 \mathrm{~h})$ & 77 & 13 & 10 & 41 & 36 \\
\hline \multicolumn{8}{|c|}{ nd not detected } \\
\hline
\end{tabular}

The phosphorylated sugars synthetized were all fully characterized by mass spectrometry and NMR spectroscopy (Fig. 5). The regioselectivity of the hexose phosphorylation catalyzed by $\mathrm{ScrK}_{\text {mitis }}$, was determined by NMR. Considering the literature, phosphorylation was expected in position 6 (Conejo et al. 2010). Indeed, ${ }^{1} \mathrm{H}$ and ${ }^{13} \mathrm{C}$ NMR spectra (Fig. S5-S10) confirmed a C6 regioselectivity of the phosphorylation (Table 3, entries 1-2, 4-8) except for L-sorbose (Table 3, 
entry 3). A position of phosphorylation elsewhere than in position 6 was also reinforced by a fragmentation in FTMS different from those obtained for the other synthesized phosphorylated hexoses (Fig. S17). The observed coupling for $\mathrm{C} 4$ and $\mathrm{C} 5$ on ${ }^{13} \mathrm{C}$ NMR spectra suggested a phosphorylation at the 5-position which was confirmed by a $2 \mathrm{D}{ }^{1} \mathrm{H}_{-}{ }^{31} \mathrm{P}$ NMR analysis showing a coupling between ${ }^{31} \mathrm{P}$ and ${ }^{1} \mathrm{H} 5$ (Fig. S18).

\section{Discussion}

The exploration of the protein natural diversity is one of the most efficient strategies to provide enzymes possessing new or improved properties. In this study, we experimentally identified 61 sugar kinases. These enzymes shared the specific signatures of the ROK family originally built from only few members, signatures which were thereby reinforced by the large set of experimentally tested kinases. Notably, we confirmed that the ATP $/ \mathrm{Mg}^{2+}$ binding site of fructokinases was EXGXT and not DXGXT (Conejo et al. 2010) as for other ROK-type sugar kinases. However, the biological function of Mak from E. coli (Uniprot ID: P23917) described as fructokinase (Miller and Raines 2004) could be questioned since it is not clusterized with fructokinases in the phylogenetic tree and its ATP $/ \mathrm{Mg}^{2+}$ binding site is DXGXT. These features consolidated the signatures predicted to partition fructokinases from other sugar kinases.

The kinases from this study were active toward various sugars and many of them were found thermotolerant. The combined analysis of the phylogeny including a careful inventory of ROK-type kinases, and our experimental data, revealed that the majority of the 61 sugar kinases from this study are mannofructokinases not related to the already known ROK-type sugar kinases, mostly described as glucokinases (21 out of the 27 known ROK-type sugar kinases according to the inventory Table S4 and Table S5). As underlined by Conejo and co-workers, carbohydrate specificity of individual ROK-type kinase is difficult to assign due to the lack of experimental data (Conejo et al. 2010). In this study, we experimentally assigned the substrate specificity of 20 ATP-dependent fructokinases and 5 ATP-dependent glucokinases previously annotated as ROK family proteins. In addition, we experimentally confirmed the predicted annotations for 23 fructokinases and 3 glucokinases. Finally, function could be assigned without ambiguity for 7 "uncharacterized proteins" revealing 6 mannofrucokinases and 1 glucokinase.

Little is known about the substrate scope of ROK-type kinases. It was generally restricted to D-fructose, D-glucose, and D-mannose. Only few were reported for other hexoses, even if some ROK-type glucokinases with broad substrate specificity were described (Table S5). To address this lack of experimental data, 
we selected one promiscuous kinase $\left(\mathrm{ScrK}_{\text {mitis }}\right)$ and undertook an in-depth kinetic parameters and substrate spectrum study. For this purpose, we determined its specific activities for all hexoses (aldoses and ketoses D- and Lseries) and also some C4 and C5 monosaccharides. ScrK $\mathrm{m}_{\text {mitis }}$ was clearly distinguished from those described in the literature by its high catalytic efficiency toward both D-mannose and D-fructose and was found to be the first purified mannofructokinase deeply characterized from the ROK family (Table 4). $\mathrm{FrK}_{\text {mobilis }}$, the only one other purified enzyme with characterized manno- and fructokinase activity, shares $38 \%$ of sequence identity with ScrK $_{\text {mitis }}$ but showed only moderate activity toward D-mannose compared to $\mathrm{ScrK}_{\text {mitis }}$. Indeed, even if their Michaelis constants $K_{\mathrm{M}}$ for D-fructose and D-mannose were similar, Vmax of $\mathrm{ScrK}_{\text {mitis }}$ for D-mannose was 500 times higher (Table 4). Furthermore, its catalytic activity toward other hexoses as D-tagatose and unnatural monosaccharides (D-altrose and D-talose) revealed its large substrate scope mostly on hexoses. As far as we know, such substrate promiscuity was never reported for any ROK-type sugar kinase (Table S4 and Table S5).

\section{Table 4}

Kinetic constants and optimal conditions of fructokinases from ROK family

\begin{tabular}{|c|c|c|c|c|c|c|c|c|c|}
\hline \multirow[b]{2}{*}{$\begin{array}{l}\text { Gene } \\
\text { name }\end{array}$} & \multirow[b]{2}{*}{$\begin{array}{c}\text { Enzyme } \\
\text { purity }\end{array}$} & \multicolumn{2}{|c|}{ D-fructose } & \multicolumn{2}{|c|}{ D-mannose } & \multicolumn{2}{|c|}{ Optimal } & \multirow[b]{2}{*}{ Cations } & \\
\hline & & $\begin{array}{c}\text { Vmax } \\
\text { (U/mg } \\
\text { protein) }\end{array}$ & $\underset{(\mathbf{m M} M)}{\mathbf{K m}}$ & $\begin{array}{c}\text { Vmax } \\
\text { (U/mg } \\
\text { protein) }\end{array}$ & $\begin{array}{c}\mathbf{K m} \\
(\mathbf{m M})\end{array}$ & $\begin{array}{c}\mathbf{T} \\
\left({ }^{\circ} \mathbf{C}\right)\end{array}$ & pH & & $\mathbf{F}$ \\
\hline $\operatorname{ScrK}_{\text {mitis }}$ & $\mathrm{P}$ & 39 & 0.73 & 90 & 0.15 & 55 & $\begin{array}{l}7- \\
10\end{array}$ & $\begin{array}{l}\mathrm{Mg}^{2+}> \\
\mathrm{Co}^{2+}> \\
\mathrm{Mn}^{2+}> \\
\mathrm{Zn}^{2+}> \\
\mathrm{Ca}^{2+}> \\
\mathrm{Ni}^{2+}\end{array}$ & $\mathrm{T}$ \\
\hline FrK $_{\text {mobilis }}$ & $\mathrm{P}$ & 0.35 & 0.7 & & & & & & a \\
\hline $\mathrm{FrK}_{\text {mobilis }}$ & $\mathrm{P}$ & 0.21 & 0.75 & 0.17 & 0.65 & & & & $\begin{array}{l}1 \\
\mathrm{a}\end{array}$ \\
\hline
\end{tabular}

One unit (U) of enzyme activity was defined as the amount of enzyme that catalyzed the conversion of $1 \mathrm{mM}$ of substrate per minute

nd not determined but activity detected, $\mathrm{P}$ purified protein, $\mathrm{CE}$ crude extract, $\mathrm{PH}$ purifiec homogeneity

*Entries are $\mathrm{N}$ terminal fragment proteins that are orphan of genes. For these fragments, against Uniprot database showed $100 \%$ of local identity with $\mathrm{N}$ terminal fragment of frur from ROK family. 


\begin{tabular}{|c|c|c|c|c|c|c|c|c|c|}
\hline \multirow[b]{2}{*}{$\begin{array}{l}\text { Gene } \\
\text { name }\end{array}$} & \multirow[b]{2}{*}{$\begin{array}{c}\text { Enzyme } \\
\text { purity }\end{array}$} & \multicolumn{2}{|c|}{ D-fructose } & \multicolumn{2}{|c|}{ D-mannose } & \multicolumn{2}{|c|}{ Optimal } & \multirow[b]{2}{*}{ Cations } & \multirow[b]{2}{*}{$\mathbf{F}$} \\
\hline & & $\begin{array}{c}\text { Vmax } \\
\text { (U/mg } \\
\text { protein) }\end{array}$ & $\underset{(\mathbf{m M})}{\mathbf{K m}}$ & $\begin{array}{c}\text { Vmax } \\
\text { (U/mg } \\
\text { protein) }\end{array}$ & $\underset{(\mathbf{m M})}{\mathbf{K m}}$ & $\begin{array}{c}\mathbf{T} \\
\left({ }^{\circ} \mathbf{C}\right)\end{array}$ & pH & & \\
\hline GmuE & $\mathrm{P}$ & 0.18 & 0.38 & & & & & & a \\
\hline $\mathrm{ScrK}_{\text {mutans }}$ & $\mathrm{CE}$ & $\begin{array}{l}0.02 \\
10^{-3}\end{array}$ & 0.77 & $\begin{array}{l}0.05 \\
10^{-4}\end{array}$ & 1 & & & & $\begin{array}{l}i \\
1\end{array}$ \\
\hline Mak & $\mathrm{CE}$ & nd & nd & & & & & & $\begin{array}{l}\mathrm{R} \\
2\end{array}$ \\
\hline Q09124* & PH & 0.2 & 0.31 & nd & nd & & $7-8$ & $\begin{array}{l}\mathrm{Mg}^{2+}> \\
\mathrm{Co}^{2+}> \\
\mathrm{Fe}^{2+}> \\
\mathrm{Mn}^{2+}> \\
\mathrm{Ni}^{2+}> \\
\mathrm{Zn}^{2+}> \\
\mathrm{Cd}^{2+}\end{array}$ & e \\
\hline Q09123* & $\mathrm{PH}$ & 0.07 & 0.4 & $\sim 0.07$ & nd & & $\begin{array}{l}6.5- \\
7.5\end{array}$ & $\begin{array}{l}\mathrm{Mg}^{2+}> \\
\mathrm{Fe}^{2+}> \\
\mathrm{Co}^{2+}> \\
\mathrm{Mn}^{2+}> \\
\mathrm{Ni}^{2+}> \\
\mathrm{Cd}^{2+}> \\
\mathrm{Zn}^{2+}> \\
\mathrm{Ca}^{2+}\end{array}$ & e \\
\hline
\end{tabular}

One unit (U) of enzyme activity was defined as the amount of enzyme that catalyzed the conversion of $1 \mathrm{mM}$ of substrate per minute

nd not determined but activity detected, $\mathrm{P}$ purified protein, $\mathrm{CE}$ crude extract, $\mathrm{PH}$ purifiec homogeneity

*Entries are $\mathrm{N}$ terminal fragment proteins that are orphan of genes. For these fragments, against Uniprot database showed $100 \%$ of local identity with $\mathrm{N}$ terminal fragment of frur from ROK family.

In addition, as far as we know, $\mathrm{ScrK}_{\text {mitis }}$ is the only purified fructokinase encoded by an identified gene for which operating conditions have been so extensively studied (Table 4). ScrK $_{\text {mitis }}$ kept more than $80 \%$ of activity between pH 7 and 10, and still 60\% at pH 6-7 and pH 10-11. Such broader $\mathrm{pH}$ range seems not shared by the two fructokinases orphan of genes (Table 4). Its metal ion requirement is in accordance with literature reported for ROK-type kinase, exemplified by the clear visualization of the binding mode between the enzyme and divalent cation in crystal structures (Nishimasu et al. 2007; Nocek et al. 2011). $\mathrm{Mg}^{2+}, \mathrm{Co}^{2+}$, and $\mathrm{Mn}^{2+}$ were found more effective on fructokinase activity 
of $\mathrm{ScrK}_{\text {mitis }}$ than $\mathrm{Zn}^{2+}, \mathrm{Ca}^{2+}$, and $\mathrm{Ni}^{2+}$. This tolerance with regard to a wide range of bivalent metal ions was similar to those reported (Table 4). In addition, despite coming from a mesophilic bacterium, it showed a very broad temperature range ( $>85 \%$ activity between 40 and $70{ }^{\circ} \mathrm{C}$ ). Maximum activity around 40 $50{ }^{\circ} \mathrm{C}$ was reported for kinases from mesophilic bacteria, like hexokinase from the Arthrobacter sp. (Mukai et al. 2003) $\left(45^{\circ} \mathrm{C}\right)$ and glucokinase from Streptomyces peucetius var. caesius (Ramos et al. 2004) $\left(42{ }^{\circ} \mathrm{C}\right)$ but without data above $50{ }^{\circ} \mathrm{C}$ reported (Table S5). $\mathrm{ScrK}_{\text {mitis }}$ seemed to distinguish from these reported enzymes by its conserved activities at $60-70{ }^{\circ} \mathrm{C}$ and from kinases from thermophilic organisms, which generally exhibit a restricted maximum activity temperature range $\left(70{ }^{\circ} \mathrm{C}\right.$ to $100{ }^{\circ} \mathrm{C}$ ) (Dorr et al. 2003; Hansen et al. 2002; Qian et al. 2013). Interestingly, $\mathrm{ScrK}_{\text {mitis }}$ thermotolerance allowed its purification by a simple cell crude extract heat treatment with however 20 to $30 \%$ loss of activity. By comparison, ScrK from Lactobacillus lactis is completely inactivated by heating treatment within $3 \mathrm{~min}$ at $65{ }^{\circ} \mathrm{C}$ (Thompson et al. 1991). It is noteworthy that from an industrial point of view, enzymatic processes at elevated temperature offer many advantages, such as higher reaction rate, improved solubility of organic substrates, and higher tolerance toward nonconventional media (Choi et al. 2015; Elleuche et al. 2014). In addition, thermostable enzymes offer better resistance against protein destabilizing factors during protein engineering processes (Littlechild 2015).

We demonstrated the biocatalytic applicability of this sugar kinase from Streptococcus mitis by synthesizing 8 phosphorylated hexoses through simple ATP-dependent phosphorylation and in situ regeneration of ATP by PEP/PK system. All the substrates were regioselectively phosphorylated in position 6 except L-sorbose which gave the 5-derivative. One hypothesis could be that the reacting conformational form in the active site is the pyranose one which eliminates any possibility of phosphorylation in position 6 , supported by structures of gluco- and fructokinases showing closed conformational forms of the substrates in the active sites (Nishimasu et al. 2007; Nocek et al. 2011). In addition, Balieu and collaborators have observed the preferred pyranose form in water for L-sorbose (Zebiri et al. 2011). We observed a trend that the enzyme better converts aldoses with S-configuration at position 2 ( $\alpha$ - or $\beta$-pyranose configuration) with preferentially $\mathrm{R}$ configuration at positions 4 (specific $\operatorname{activity}_{(\mathrm{D}-\text {-altrose and D-mannose) }}>$ specific activity $_{(\mathrm{D} \text {-talose) }}$ ), as well as ketoses with $\mathrm{S}$ configuration at position 3 , with preferentially $\mathrm{R}$ configuration at position 4

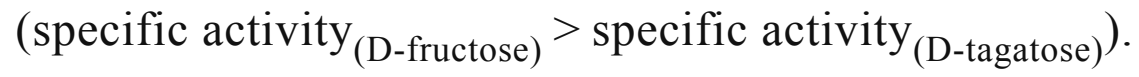

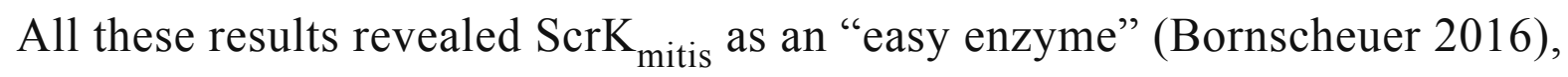
efficient and versatile biocatalyst for the synthesis of phosphorylated sugars, 
compounds of particular interest in the study of various metabolic diseases (Wohlgemuth et al. 2017).

\section{Acknowledgments}

The authors would like to thank Jean-François Gallard (ICSN, France) for ${ }^{1} \mathrm{H}$ ${ }^{31}$ P NMR experiments, Olek Maciejak and Marie-Jeanne Clément (SABNP, INSERM U 1204-Université d'Evry Val-d'Essonne, Université Paris-Saclay, France) for assistance in ${ }^{1} \mathrm{H}$ and ${ }^{13} \mathrm{C}$ NMR experiments, the Region Ile de France for financial support of the $600 \mathrm{MHz}$ NMR spectrometer, Alain Perret for fruitful discussions and proofreading of the manuscript, and Christine Pelle and Peggy Sirvain for nickel affinity chromatography purification of $\mathrm{ScrK}_{\text {mitis }}$. We thank C. Rivoire (the Swiss-Prot Group at the SIB Swiss Institute of Bioinformatics) for earlier Uniprot identifier assignments.

Compliance with ethical standards

Conflict of interest The authors declare that they have no conflict of interest.

Ethical approval This article does not contain any studies with human participants or animals performed by any of the authors.

\section{Electronic supplementary material}

\section{ESM 1}

(PDF $2580 \mathrm{~kb})$

\section{References}

$\mathrm{AQ}_{4}$

Bastard K, Smith AA, Vergne-Vaxelaire C, Perret A, Zaparucha A, De MeloMinardi R, Mariage A, Boutard M, Debard A, Lechaplais C, Pelle C, Pellouin V, Perchat N, Petit JL, Kreimeyer A, Medigue C, Weissenbach J, Artiguenave F, De Berardinis V, Vallenet D, Salanoubat M (2014) Revealing the hidden functional diversity of an enzyme family. Nat Chem Biol 10(1):42-49. https://doi.org/10.1038/nchembio.1387

Bornscheuer UT (2016) Biocatalysis: successfully crossing boundaries. Angew Chem Int Ed Eng 55(14):4372-4373.

https://doi.org/10.1002/anie.201510042 
Charmantray F, Hélaine V, Legeret B, Hecquet L (2009) Preparative scale enzymatic synthesis of D-sedoheptulose-7-phosphate from $\beta$-hydroxypyruvate and D-ribose-5-phosphate. J Mol Catal B Enzym 57(1-4):6-9.

https://doi.org/10.1016/j.molcatb.2008.06.005

Choi JM, Han SS, Kim HS (2015) Industrial applications of enzyme biocatalysis: current status and future aspects. Biotechnol Adv 33:1443-1454. https://doi.org/10.1016/j.biotechadv.2015.02.014

Conejo MS, Thompson SM, Miller BG (2010) Evolutionary bases of carbohydrate recognition and substrate discrimination in the ROK protein family. J Mol Evol 70(6):545-556. https://doi.org/10.1007/s00239-010-93511

Davids T, Schmidt M, Böttcher D, Bornscheuer UT (2013) Strategies for the discovery and engineering of enzymes for biocatalysis. Curr Opin Chem Biol 17(2):215-220. https://doi.org/10.1016/j.cbpa.2013.02.022

de Berardinis V, Guérard-Hélaine C, Darii E, Bastard K, Hélaine V, Mariage A, Petit JL, Poupard N, Sánchez-Moreno I, Stam M, Gefflaut T, Salanoubat S, Lemaire M (2017) Expanding the reaction space of aldolases using hydroxypyruvate as a nucleophilic substrate. Green Chem 19:519-526. https://doi.org/10.1039/C6GC02652D

Desvergnes S, Courtiol-Legourd S, Daher R, Dabrowski M, Salmon L, Therisod M (2012) Synthesis and evaluation of malonate-based inhibitors of phosphosugar-metabolizing enzymes: class II fructose-1,6-bis-phosphate aldolases, type I phosphomannose isomerase, and phosphoglucose isomerase. Bioorg Med Chem 20(4):1511-1520. https://doi.org/10.1016/j.bmc.2011.12.050

Dorr C, Zaparty M, Tjaden B, Brinkmann H, Siebers B (2003) The hexokinase of the hyperthermophile Thermoproteus tenax. ATP-dependent hexokinases and ADP-dependent glucokinases, two alternatives for glucose phosphorylation in Archaea. J Biol Chem 278(21):18744-18753. https://doi.org/10.1074/jbc.M301914200

Elleuche S, Schröder C, Sahm K, Antranikian G (2014) Extremozymesbiocatalysts with unique properties from extremophilic microorganisms. Curr Opin Biotechnol 29:116-123. https://doi.org/10.1016/j.copbio.2014.04.003 
Franke FP, Kapuscinski M, Lyndon P (1985) Synthesis and n.m.r. characterization of intermediates in the L-type pentose phosphate cycle. Carbohydr Res 143:69-76. https://doi.org/10.1016/S0008-6215(00)90696-7

Guérard-Hélaine C, Debacker M, Clapés P, Szekrenyi A, Hélaine V, Lemaire M (2014) Efficient biocatalytic processes for highly valuable terminally phosphorylated C5 to C9 D-ketoses. Green Chem 16(3):1109-1113. https://doi.org/10.1039/c3gc42140f

Guérard-Hélaine C, de Berardinis V, Besnard-Gonnet M, Darii E, Debacker M, Debard A, Fernandes C, Hélaine V, Mariage A, Pellouin V, Perret A, Petit J-L, Sancelme M, Lemaire M, Salanoubat M (2015) Genome mining for innovative biocatalysts: new dihydroxyacetone aldolases for the chemist's toolbox. ChemCatChem 7(12):1871-1879.

https://doi.org/10.1002/cctc.201500014

Hansen T, Reichstein B, Schmid R, Schönheit P (2002) The first Archaeal ATP-dependent glucokinase, from the hyperthermophilic crenarchaeon Aeropyrum pernix, represents a monomeric, extremely thermophilic ROK glucokinase with broad hexose specificity. J Bacteriol 184(21):5955-5965. https://doi.org/10.1128/jb.184.21.5955-5965.2002

Heinonen JK, Lahti RJ (1981) A new and convenient colorimetric determination of inorganic orthophosphate and its application to the assay of inorganic pyrophosphatase. Anal Biochem 113(2):313-317. https://doi.org/10.1016/0003-2697(81)90082-8

Hélaine V, Mahdi R, Sudhir Babu GV, de Berardinis V, Wohlgemuth R, Lemaire M, Guérard-Hélaine C (2015) Straightforward synthesis of terminally phosphorylated L-sugars via multienzymatic cascade reactions. Adv Synth Catal 357(8):1703-1708. https://doi.org/10.1002/adsc.201500190

Holmes KC, Sander C, Valencia A (1993) A new ATP-binding fold in actin, hexokinase and Hsc70. Trends Cell Biol 3(2):53-59. https://doi.org/10.1016/0962-8924(93)90161-S

Howe K, Bateman A, Durbin R (2002) QuickTree: building huge neighbourjoining trees of protein sequences. Bioinformatics 18(11):1546-1547. https://doi.org/10.1093/bioinformatics/18.11.1546

Jaworek D, Welsch J (1985) Adenosine 5-diphosphate and adenosine 5monophosphate. In: Bergmeyer HU, Bergmeyer J, Graß1 M (eds) Methods 
Enz Anal, vol 7, pp 365-370

Katoh K, Misawa K, Kuma K, Miyata T (2002) MAFFT: a novel method for rapid multiple sequence alignment based on fast Fourier transform. Nucleic Acids Res 30(14):3059-3066

Koerner Jr TA, Voll RJ, Cary LW, Younathan ES (1980) Carbon-13 nuclear magnetic resonance studies and anomeric composition of ketohexose phosphates in solution. Biochemistry 19(12):2795-2801.

https://doi.org/10.1021/bi00553a040

Kreimeyer A, Perret A, Lechaplais C, Vallenet D, Medigue C, Salanoubat M, Weissenbach J (2007) Identification of the last unknown genes in the fermentation pathway of lysine. J Biol Chem 282(10):7191-7197. https://doi.org/10.1074/jbc.M609829200

Kreuzer P, Gartner D, Allmansberger R, Hillen W (1989) Identification and sequence analysis of the Bacillus subtilis W23 xylR gene and xyl operator. J Bacteriol 7(171):3840-3845. https://doi.org/10.1021/bi00553a040

Larion M, Moore LB, Thompson SM, Miller BG (2007) Divergent evolution of function in the ROK sugar kinase superfamily: role of enzyme loops in substrate specificity. Biochemistry 46(47):13564-13572. https://doi.org/10.1021/bi700924d

Letunic I, Bork P (2016) Interactive tree of life (iTOL) v3: an online tool for the display and annotation of phylogenetic and other trees. Nucleic Acids Res 44(W1):W242-W245. https://doi.org/10.1093/nar/gkw290

Littlechild JA (2015) Enzymes from extreme environments and their industrial applications. Front Bioeng Biotechnol 3:161. https://doi.org/10.3389/fbioe.2015.00161

Miller BG, Raines RT (2004) Identifying latent enzyme activities: substrate ambiguity within modern bacterial sugar kinases. Biochemistry 43(21):63876392. https://doi.org/10.1021/bi049424m

Mukai T, Kawai S, Matsukawa H, Matuo Y, Murata K (2003) Characterization and molecular cloning of a novel enzyme, inorganic polyphosphate/ATP-glucomannokinase, of Arthrobacter sp. strain KM. Appl Environ Microbiol 69(7):3849-3857. https://doi.org/10.1128/aem.69.7.38493857.2003 
Nishimasu H, Fushinobu S, Shoun H, Wakagi T (2007) Crystal structures of an ATP-dependent hexokinase with broad substrate specificity from the hyperthermophilic archaeon Sulfolobus tokodaii. J Biol Chem 282(13):99239931. https://doi.org/10.1074/jbc.M610678200

Nocek B, Stein AJ, Jedrzejczak R, Cuff ME, Li H, Volkart L, Joachimiak A (2011) Structural studies of ROK fructokinase YdhR from Bacillus subtilis: insights into substrate binding and fructose specificity. J Mol Biol 406(2):325-342. https://doi.org/10.1016/j.jmb.2010.12.021

Plumbridge J (2001) DNA binding sites for the Mlc and NagC proteins: regulation of nagE, encoding the $\mathrm{N}$-acetylglucosamine-specific transporter in Escherichia coli. Nucleic Acids Res 29(2):506-514.

https://doi.org/10.1093/nar/29.2.506

Postma PW, Lengeler JW, Jacobson GR (1993)

Phosphoenolpyruvate:carbohydrate phosphotransferase systems of bacteria. Microbiol Rev 3(57):543-594

Qian Z, Zhao J, Bai X, Tong W, Chen Z, Wei H, Wang Q, Liu S (2013) Thermal stability of glucokinases in Thermoanaerobacter tengcongensis. Biomed Res Int 2013:646539. https://doi.org/10.1155/2013/646539

Ramos I, Guzman S, Escalante L, Imriskova I, Rodriguez-Sanoja R, Sanchez S, Langley E (2004) Glucose kinase alone cannot be responsible for carbon source regulation in Streptomyces peucetius var. caesius. Res Microbiol 155(4):267-274. https://doi.org/10.1016/j.resmic.2004.01.004

Rother C, Gutmann A, Gudiminchi R, Weber H, Lepak A, Nidetzky B (2017) Biochemical characterization and mechanistic analysis of the levoglucosan kinase from Lipomyces starkeyi. Chembiochem 19:596-603. https://doi.org/10.1002/cbic.201700587

Rudolph FB, Fromm HJ (1971) A study on the kinetics and mechanism of Dlyxose and D-xylose activation of the adenosine triphosphatase activity associated with yeast hexokinase. J Biol Chem 7(246):2104-2110

Sánchez-Moreno I, Hélaine V, Poupard N, Charmantray F, Légeret B, Hecquet L, García-Junceda E, Wohlgemuth R, Guérard-Hélaine C, Lemaire M (2012) One-pot cascade reactions using fructose-6-phosphate aldolase: efficient synthesis of D-arabinose 5-phosphate, D-fructose 6-phosphate and 
analogues. Adv Synth Catal 354(9):1725-1730.

https://doi.org/10.1002/adsc.201200150

Sato Y, Poy F, Jacobson GR, Kuramitsu HK (1989) Characterization and sequence analysis of the scrA gene encoding enzyme IIScr of the Streptococcus mutans phosphoenolpyruvate-dependent sucrose phosphotransferase system. J Bacteriol 1(171):263-271. https://doi.org/10.1128/JB.171.1.263-271

Sato Y, Yamamoto Y, Kizaki H, Kuramitsu HK (1993) Isolation, characterization and sequence analysis of the scrK gene encoding fructokinase of Streptococcus mutans. J Gen Microbiol 139(5):921-927. https://doi.org/10.1099/00221287-139-5-921

Schorken U (1998) Thiamin-dependent enzymes as catalysts in chemoenzymatic syntheses. Biochim Biophys Acta 1385(E 2):229-243

Scopes RK, Testolin V, Stoter A, Griffiths-Smith K, Algar EM (1985) Simultaneous purification and characterization of glucokinase, fructokinase and glucose-6-phosphate dehydrogenase from Zymomonas mobilis. Biochem J 228(3):627-634

Shaeri J, Wright I, Rathbone EB, Wohlgemuth R, Woodley JM (2008) Characterization of enzymatic D-xylulose 5-phosphate synthesis. Biotechnol Bioeng 101(4):761-767. https://doi.org/10.1002/bit.21949

Sizemore C, Buchner E, Rygus T, Witke C, Gotz F, Hillen W (1991) Organization, promoter analysis and transcriptional regulation of the Staphylococcus xylosus xylose utilization operon. Mol Gen Genet 227(3):377-384. https://doi.org/10.1007/BF00273926

Solovjeva ON, Kochetov GA (2008) Enzymatic synthesis of d-xylulose 5phosphate from hydroxypyruvate and d-glyceraldehyde-3-phosphate. J Mol Catal B Enzym 54(3-4):90-92. https://doi.org/10.1016/j.molcatb.2007.12.016

Sproul AA, Lambourne LT, Jean-Jacques DJ, Kornberg HL (2001) Genetic control of manno(fructo)kinase activity in Escherichia coli. PNAS 98(26):15257-15259. https://doi.org/10.1073/pnas.211569798

Thompson J, Sackett DL, Donkersloot JA (1991) Purification and properties of fructokinase I from Lactococcus lactis. Localization of scrK on the sucrose-nisin transposon Tn5306. J Biol Chem 33(266):22626-22633 
Thompson J, Nguyen NY, Robrish SA (1992) Sucrose fermentation by Fusobacterium mortiferum ATCC 25557: transport, catabolism, and products. J Bacteriol 10(174):3227-3235

Titgemeyer F, Reizer J, Reizer A, Saier MH Jr (1994) Evolutionary relationships between sugar kinases and transcriptional repressors in bacteria. Microbiology 140(Pt 9):2349-2354. https://doi.org/10.1099/13500872-140-92349

Uehara T, Park JT (2004) The N-acetyl-D-glucosamine kinase of Escherichia coli and its role in murein recycling. J Bacteriol 186(21):7273-7279. https://doi.org/10.1128/JB.186.21.7273-7279.2004

Vergne-Vaxelaire C, Bordier F, Fossey A, Besnard-Gonnet M, Debard A, Mariage A, Pellouin V, Perret A, Petit J-L, Stam M, Salanoubat M, Weissenbach J, De Berardinis V, Zaparucha A (2013) Nitrilase activity screening on structurally diverse substrates: providing biocatalytic tools for organic synthesis. Adv Synth Catal 355(9):1763-1779. https://doi.org/10.1002/adsc.201201098

Weisser P, Kramer R, Sprenger GA (1996) Expression of the Escherichia coli pmi gene, encoding phosphomannose-isomerase in Zymomonas mobilis, leads to utilization of mannose as a novel growth substrate, which can be used as a selective marker. Appl Environ Microbiol 11(62):4155-4161

Wohlgemuth R (2009) C2-Ketol elongation by transketolase-catalyzed asymmetric synthesis. J Mol Catal B Enzym 61(1-2):23-29. https://doi.org/10.1016/j.molcatb.2009.04.001

Wohlgemuth R, Liese A, Streit W (2017) Biocatalytic phosphorylations of metabolites: past, present, and future. Trends Biotechnol 35(5):452-465. https://doi.org/10.1016/j.tibtech.2017.01.005

Zebiri I, Balieu S, Guilleret A, Reynaud R, Haudrechy A (2011) The chemistry of L-Sorbose. Eur J Org Chem 2011(16):2905-2910. https://doi.org/10.1002/ejoc.201001578

Zembrzuski B, Chilco P, Liu XL, Liu J, Conway T, Scopes R (1992) Cloning, sequencing, and expression of the Zymomonas mobilis fructokinase gene and structural comparison of the enzyme with other hexose kinases. J Bacteriol 11(174):3455-3460 
Zhao S, Kumar R, Sakai A, Vetting MW, Wood BM, Brown S, Bonanno JB, Hillerich BS, Seidel RD, Babbitt PC, Almo SC, Sweedler JV, Gerlt JA,

Cronan JE, Jacobson MP (2013) Discovery of new enzymes and metabolic pathways using structure and genome context. Nature 502(7473):698-702. https://doi.org/10.1038/nature12576 